\title{
Observation on Achnanthes Bory sensu stricto (Bacillariophyceae) from subaerial habitats in Macedonia and comparison with the type material of A. coarctata (BrébISSON ex W. SMith) Grunow, $A$. coarctata var. sinaensis Hustedt and $A$. intermedia KütZING
}

\author{
Slavica Tofilovska ${ }^{1}$, Carlos E. Wetzel ${ }^{2}$, Luc Ector ${ }^{2} \&$ Zlatko Levkov $^{1 *}$ \\ ${ }^{1}$ Institute of Biology, Faculty of Natural Sciences, Ss Cyril and Methodius University, Gazi Baba bb, 1000 \\ Skopje, R. Macedonia; *Corresponding authore-mail: zlevkov@iunona.pmf.ukim.edu.mk \\ ${ }^{2}$ Department of Environment and Agro-biotechnologies (EVA), Public Research Centre - Gabriel Lippmann, \\ Rue du Brill 41, L-4422 Belvaux, Luxembourg
}

\begin{abstract}
Four species of Achnanthes sensu stricto have been observed in several subaerial habitats/localities in Macedonia. The morphological features of all recorded species have been described based on light and scanning electron microscope observations. Two species posses similar morphological features as already described species and were identified as $A$. coarctata (BrÉBISSON ex W. SMITH) Grunow and A. sinaensis (HustedT) stat. nov. Two species have unique set of characters that separate them from the known species and are described in this study as $A$. pseudocoarctata Levkov et Tofilovska sp. nov. and $A$. prominula Levkov et TofilovsKa sp. nov. All recorded species were compared with the type populations including $A$. coarctata, $A$. coarctata var. sinaensis HustedT, and A. intermedia KützING.

Observations of the syntype populations of $A$. coarctata give precise frame of the morphological variability of the species. Achnanthes pseudocoarctata appears similar to A. coarctata, but can be easily differentiated by the morphological and ultrastructural features of the rapheless valve. Achnanthes coarctata var. sinaensis has distinct morphological characters that make clear separation from A. coarctata, and therefore we propose a new status of this taxon with raising its rank to a species level. Achnanthes prominula appears similar to A. intermedia, but from latter can be easily separated by the position of the rapheless sternum. From other species with lanceolate or elliptic-lanceolate valves, $A$. prominula can be differentiated by the valve shape, position of the rapheless sternum, central area, stria and areola density.
\end{abstract}

Key words: Achnanthes, taxonomy, new species, new status, Macedonia, type material

\section{INTRODUCTION}

The genus Achnanthes was described by BORY in 1822 . Since that time there have been many changes from its initial description. More than 900 taxa of Achnanthes sensu lato have been recorded (VANLANDINGHAM 1967), but in the last two decades the genus has been divided into several new genera (BUKHTIYAROva \& Round 1996; Round \& BukHTIYAROVA 1996; Round \& BASSON 1997; Krammer \& LANGE-Bertalot 2004). In this new framework, Achnanthes sensu stricto comprises around 150 taxa (ToyOdA et al. 2005a), mostly occurring in the marine and brackish habitats, and usually epiphytic on filamentous seaweeds or some diatom species (Toyoda et al. 2003, 2005c). The designation of the generitype for Achnanthes sensu stricto was made by BOYER (1927), but the formal typification was provided by TOYODA et al. (2005a) based on Echinella stipitata Lyngbye (=A. brevipes C. Agardh).

Most of the studies on Achnanthes sensu stricto refer to marine species (MCINTIRE \& REIMER 1974; BlunN \& Evans 1981; Toyoda et al. 2005b, 2006a, 2010). However, in the last few years new information on species found in subaerial habitats has been provided (HofFMANN 2002; TOYODA et al. 2006b, 2009; PoulíčKovÁ \& HAŠLer 2007; Lowe et al. 2009). According to Gonzalves \& Gandhi (1952), GANdhi (1960, 1966), VAN DE ViJVer et al. (2002), Toyoda \& Williams $(2004,2005)$, Metzeltin et al. (2005), Toyoda et al. (2005a, 2006b) and Lowe et al. (2009), only a few freshwater Achnanthes sensu stricto species have been described, including $A$. coarctata (Brébisson) Grunow, A. crenulata Grunow, $A$. crenulata var. elliptica H.P. GANDHI, A. crenulata var. linearis H.P. GANDHI, A. elata (LEUdUGER-Fortmorel) H.P. Gandhi, A. elata var. curvula H.P. GANDHI, $A$. felinophila R.L. Lowe et A.R. SHERwoOd in Lowe et al., A. gondwana Metzeltin et Lange-Bertalot, A. inflata (KützInG) Grunow, A. inflata var. gibba H.P. GANDH, A. inflata var. javanica H.P. GANDHI, A. inflatagrandis 
Metzeltin, Lange-Bertalot et García-Rodríguez, $A$. longboardia A.R. SHeRwood et R.L. Lowe in Lowe et al., A. mauiensis R.L. Lowe et A.R. SHERwOOd in LowE et al., A. naviformis VAN DE VIJVER et BEYENS in VAN DE Vijver et al., $A$. polynesica Lange-Bertalot et Werum, A. smithiana (Greville) K. Toyoda et D.M. Williams, $A$. subelata Metzeltin, Lange-Bertalot et García-Rodríguez, A. taylorensis D.E. Kellogg et al., A. tumescens A.R. SHerwood et R.L. Lowe in Lowe et al., and A. undulorostrata R.L. Lowe et A.R. SHERwOOD in Lowe et al.

Data for the taxonomy and distribution of Achnanthes $s$. $s$. in Macedonia are scarce. So far there are only two records of Achnanthes in Macedonia. JuRILJ (1954), in his observations of Lake Ohrid diatoms, recorded and depicted a single valve of $A$. brevipes (op. cit. fig. 22a). JuRILJ (1954, p. 123) stated that the population from Lake Ohrid is larger than the type population, and that according to morphological features is closely related to the populations from fossil deposits instead of recent marine populations. In the recent observations on diatom flora from Lake Ohrid (LEVKOv et al. 2007) and in the observations on JURILJ's authentic material (LEVKOV unpubl. data) specimens of A. brevipes were not recorded. Therefore, the identity of this freshwater taxon remains open. The second record of Achnanthes $s$. $s$. was provided by PETROvSKA \& Stojanov (1975). In their observations of algal flora from subaerial habitats only $A$. coarctata (BRÉBISSON ex W. Sмiтн) Grunow was recorded.

A study on the diatoms from subaerial habitats in Macedonia has recently begun. Four species of the genus Achnanthes have been found, all with high abundance. Comparison with relevant type material allowed the identification of $A$. coarctata and $A$. sinaensis and two further species with different morphological features to taxa already known, which are described as new species: $A$. pseudocoarctata and A. prominula.

\section{Material ANd Methods}

The samples from Macedonia examined in this study have been collected during various campaigns from 1995 until 2012. The samples (ca. 1000) originated from different localities in Macedonia. Two samples with high abundance of Achnanthes species were used for detailed light microscope (LM) and scanning electron microscope (SEM) observations. The first sample was collected from wet rock on Osogovo Mountain (Acc. No. 003741 in MKNDC), and the second sample was collected from wet moss at the entrance of cave Peshti (Acc. No. 006647 in MKNDC).

The organic content was removed from the samples by the method of acid digestion, with the addition of $2 \mathrm{ml}$ of $\mathrm{K}_{2} \mathrm{MnO}_{4}$ and $4 \mathrm{ml}$ of $\mathrm{HCl}$ to a small (ca. $2 \mathrm{ml}$ ) subsample. Permanent slides were mounted with Naphrax ${ }^{\circledR}$. Slide observations were performed with a Nikon E-80i light microscope, and photomicrographs were taken with a Nikon Coolpix 600 digital camera. For scanning electron microscopy (SEM), a small amount of the suspensions were filtered and rinsed with additional deionized water through a $10 \mu \mathrm{m}$ Isopore ${ }^{\mathrm{TM}}$ polycarbonate membrane filter (Merck Millipore ${ }^{\circledR}$ ) with a vacuum pump. Filters were mounted on aluminum stubs using double side carbon tape and coated with platinum $(30 \mathrm{~nm})$ using a BAL-TEC MED 020 Modular high vacuum coating system for $30 \mathrm{~s}$ at 100 $\mathrm{mA}$. An ultra-high-resolution analytical field emission (FE) scanning electron microscope Hitachi SU-70 (Hitachi HighTechnologies, Europe, $\mathrm{GmbH}$ ) operated at $5 \mathrm{kV}$ and $10 \mathrm{~mm}$ distance was used for the analysis. SEM images were taken using the lower (SE-L) detector signal.

The type slides are deposited at the Macedonian National Diatom Collection (MKNDC) at the Institute of Biology in Skopje, Macedonia and isotype slides are deposited at the National History Museum in London (BM) and at the Friedrich Hustedt Centre for Diatom Study, Bremerhaven (BRM).

The syntype slides for $A$. coarctata (BM 24114, BM 24109, BM 46400) and A. intermedia KüTZING (BM 18472) have been observed in the National History Museum in London. Lectotype and isolectotype slides for A. coarctata var. sinaensis (MA4/42, MA4/49) have been observed in the Friedrich Hustedt Centre for Diatom Study, Bremerhaven (BRM). The authentic materials for SEM analyses were obtained from BRM (A. coarctata var. sinaensis) and National Botanic Garden of Belgium, Meise (BR) (A. coarctata).

Terminology for valve morphology and ultrastructure follows Round et al. (1990) and Cox (2006): Concave valve is raphid and labeled as $\mathrm{R}$-valve and convex valve is rapheless and labeled as $\mathrm{P}-$ valve.

\section{Results AND Discussion}

Six species belonging to Achnanthes $s . s$. have been observed in the studied samples from Macedonia. Two taxa were recorded as extremely rare with just few valves observed on the slides. Four species have higher abundance in the samples mentioned above and thus they are taken into consideration of this study. Their morphological and ultrastructural features are described based on LM and SEM observations and compared with the most similar taxa.

Achnanthes coarctata (BRÉBISSON ex W. SMITH) Grunow (Figs 1a-aa, 2a-f, 3a-f, 4a-ab, 5a-y, 6a-h)

LM observations (Figs 1a-aa): Frustules are flexed in the girdle view with a concave $\mathrm{R}-$-valve and convex $\mathrm{P}-$ valve. Valves are linear-lanceolate with constriction in the mid-valve. Valve apices are attenuated and narrowly rounded in larger specimens to rostrate and rounded in smaller specimens. Valve length is 29.0 $44.5 \mu \mathrm{m}$, valve width is $7.0-9.5 \mu \mathrm{m}$. R-valve (Figs $1 \mathrm{a}-\mathrm{m})$ : Axial area is narrow, slightly curved. Central area is broad panduriform stauros reaching the valve margin. Raphe is lateral, with curved raphe branches. Proximal raphe fissures are expanded into large central pores, distal fissures are unilaterally deflected. Striae are coarsely punctate, strongly radiate throughout, 12 
14 in $10 \mu \mathrm{m}$. P-valve (Figs 1o-aa): Rapheless sternum is narrow, but distinct located close to the valve margin. Striae are finely punctate, parallel in the mid-valve, becoming strongly radiate towards the apices, 12-14 in $10 \mu \mathrm{m}$. Areolae are fine, but distinct with LM, 18-20 in $10 \mu \mathrm{m}$.

SEM observations R-valve (Figs 2a-f): The outer surface of $\mathrm{R}$-valve is slightly flexed (Fig. 2a). The central area is flat without markings (Figs 2b, c, d), while internally the central area is stauros-shaped and thickened (Figs 2e, f). The raphe has central position and is weakly curved (Figs 2b, c). Proximal raphe fissures are widened into tear-drop-shaped central pores (Fig. 2d). Distally, the raphe fissures are prolonged, abruptly unilaterally deflected and extending onto the valve mantle (Fig. 2c). Internally the central endings are hooked-shaped (Fig. 2f), while the distal endings terminate with small helictoglossae (Fig. 2e). Striae are uniseriate composed of round areolae. Areolae externally have recessed foramina and are occluded by cribra (Fig. 2d). The perforations in cribrate pores are round. Cribrum is attached by 3 (rarely 4) struts to the areolae wall (Fig. 2d). Internally, the striae are separated by strongly thickened virgae. Areolae have round openings with noticeably recessed cribra (Fig. 2f).

P-valve (Figs 3a-f): The external surface of the $\mathrm{P}-$ valve is flexed with convex mid-valve (Fig. 3a). Strongly thickened marginal ridge is present along the valve face/mantle junction. The transition from the valve face to valve mantle is abrupt (Fig. 3b). Spines have not been observed. Terminal orbiculi are present on the valve mantle on each pole (Fig. 3d). Externally, terminal orbiculus has elongated opening and it is occluded with a single flap of silica (Fig. 3c). Occlusion of the terminal orbiculus has different structure than the cribrum of the areolae (Fig. 3c). The rapheless sternum is narrow but distinct, located near the valve margin. Internally, sternum appears as a narrow hyaline area near the valve margin (Fig. 3d). Striae are uniseriate composed of round areolae. The size of areolae on $\mathrm{P}$ valve is the same as the areolae on $\mathrm{R}$-valve. Striae are continuing on the valve mantle. The areolae adjust to the marginal ridge are larger, surrounded by strongly thickened wall (Figs 3b, c). Externally, the areolae are occluded by cribra. Internally, the striae are separated by strongly thickened virgae (Fig. 3e). Areolae have round opening with clearly visible internal cribra structure (Fig. 3f).

Notes: Achnanthes coarctata was first described by BrÉBISSON (in SMith 1855, p. 8) as a species of Achnanthidium, A. coarctatum BRÉBISSON, and later transferred to Achnanthes by GRUNOw in CLEVE \& GRUNOW (1880, p. 20). SMith (1855) noted as type material "in Kütz. Sp. Alg. P. 54, ad specim. authen. quae dedit am. De Brébisson", but he also gave as syntype localities "Cave near Royat" and "Grassmere, Westmoreland, Aug. 1853”. Slides from all three samples are present in the Natural History Museum, London (BM) and were observed in this study. The slide BM 24114 was made from a sample from Falaise (labeled "M. de Brébisson") and contains several valves of $A$. coarctata. Most of the specimens are covered with particles or contain air-bubbles resulting in low quality LM images. The most representative specimens are given on Figs 4aa-ab. A slide from Grassmere, Westmoreland, UK (Slide BM 24109) contains more specimens (Figs 5a-y) which are similar to the type specimens and share morphological features of A. coarctata sensu stricto. SEM observations of the population from Grassmere show that both populations from Osogovo Mountain (Figs 1a-aa, $2 \mathrm{a}-\mathrm{f}, 3 \mathrm{a}-\mathrm{f}$ ) and Grassmere (Figs 5a-y, 6a-h) share the same morphological and ultrastructural features. Most importantly, they share the differential features of the shape of the cribrate occlusions and the stria and areola density.

The slide from Cave near Royat, France (BM 46400), contains two distinct taxa (Figs 4a-z, 10a-v) which differ in several characters such as stria and areola density, number of areolae on valve mantle. The first population (Figs $4 \mathrm{a}-\mathrm{z}$ ), with respect to the morphological characteristics closely resembles to the population from Falaise (BM 24114), while the second population (Figs $10 \mathrm{a}-\mathrm{v}$ ), characterized by coarser and more distantly spaced striae and areolae, is close to the taxon observed in this study (Figs 7a-ad) and described here as $A$. pseudocoarctata sp. nov.

Ecology and distribution: Freshwater, aerophytic species, usually occurs as epiphyte on wet mosses or wet rocks. Abundant in many samples from subaerial habitats.

\section{Achnanthes pseudocoarctata Levkov et TofiLovskA sp. nov. (Figs 7a-ad, 8a-f, 9a-g, 10a-v)}

\section{Description}

LM observations (Figs 7a-ad): Valves are linearlanceolate with constriction in the mid-valve. Valve apices are broadly subrostrate to not protracted and broadly rounded in smaller specimens. Valve length is $25.0-37.0 \mu \mathrm{m}$, valve width is $6.0-8.5 \mu \mathrm{m}$. $\mathrm{R}$-valve (Figs $7 \mathrm{a}-\mathrm{n}$ ): Axial area is narrow, slightly curved. Central area is broad rectangular to panduriform stauros reaching the valve margin. Raphe is lateral, with curved raphe branches. Proximal raphe fissures are expanded into large central pores, slightly deflected on one side, distal fissures are unilaterally deflected on the opposite side. Striae are coarsely punctate, radiate throughout the valve, $12-13$ in $10 \mu \mathrm{m}$. P-valve (Figs $7 \mathrm{p}-\mathrm{ad})$ : Rapheless sternum is narrow, but distinct, located close to the valve margin, but is not following the line of valve margin. Striae are coarse, parallel in the mid-valve, becoming radiate towards the apices, and strongly curved at the end of the apices, $8-10$ in 10 $\mu \mathrm{m}$. Areolae are coarse, $10-13$ in $10 \mu \mathrm{m}$. 
SEM observations R-valve (Figs 8a-f): The external surface of $\mathrm{R}$-valve is slightly flexed in the mid-valve (Fig. 8a). The central area is flat without markings (Figs $8 \mathrm{~b}, \mathrm{c})$, while internally the central area is rectangular shaped and thickened with small depression in the middle (Fig. 8f). The raphe has central position and is weakly curved (Figs 8a, b). Proximal raphe fissures are widened into tear-drop-shaped central pores (Fig. $8 \mathrm{c}$ ). Distally, the raphe fissures are prolonged, abruptly unilaterally deflected and extending almost till the end of valve mantle (Figs $8 \mathrm{~b}, \mathrm{~d}$ ). Internally the central endings are hooked-shaped in the same direction (Fig. 8f), while the distal endings terminate with small helictoglossae (Fig. 8e). Striae are uniseriate composed of round areolae. Areolae externally have recessed foramina and are occluded by cribra (Fig. 8d). There are 1 or 2 round cribrate perforations. Cribrum in the middle is attached by 2 struts to the areolae wall (Fig. $8 d)$. Internally, the striae are separated by strongly thickened virgae (Fig. 8e) and areolae have round openings with noticeably recessed cribra (Fig. 8f).

P-valve: The external surface of the $\mathrm{P}-$ valve is flexed with convex mid-valve (Fig. 9a). Strongly thickened marginal ridge is present along the valve face/mantle junction. The transition from the valve face to valve mantle is abrupt (Fig. 9b). Spines have not been observed. Terminal orbiculi are present on the valve mantle on each pole, at the same side (Fig. 9b). Externally, terminal orbiculus has elongated opening and it is occluded with a single flap of silica (Fig. 9c). Occlusion of the terminal orbiculus has different structure than the cribrum of the areolae (arrow on Fig. 9c). The rapheless sternum is narrow but distinct, located near the valve margin. Internally, sternum appears as a narrow hyaline area near the valve margin (Figs 9e, f). Striae are uniseriate composed of round areolae. Areolae are occluded by cribra, recessed and surrounded by strongly thickened wall (Figs 9b, c). Cribrum is attached by 2 (rarely 3) struts to the areolae wall (Fig. 9c). There is small number of round perforations in the cribrum. The size of areolae on $\mathrm{P}$ valve has similar size as the areolae on $\mathrm{R}$-valve. Striae are continuing on the valve mantle. The areolae adjust to the marginal ridge are larger than areolae on $\mathrm{P}_{-}$ valve, surrounded by strongly thickened wall (Figs 9a, d). Externally, the areolae are occluded by cribra (Fig. 9d). Internally, the striae are separated by strongly thickened virgae and areolae have clearly visible internal cribra structure (Fig. 9g).

Holotype (designated here): Slide 006647/B in MKDNC, specimen representing the holotype is Fig. $7 \mathrm{~d}$.

Isotypes: Slide BRM ZU9/28, BM 101685.

Type locality: Mountain Jakupica, near river Babuna, cave Peshti, Macedonia, Lat.: 41 ${ }^{\circ} 40^{\prime} 11.38^{\prime}$ N. Long. $21^{\circ} 46^{\prime} 55.65^{\prime \prime} \mathrm{E}$.

Type material: Wet mosses and mud, collection date: 21.04.2012. Accession No. MKDNC 006647.
Collected by S. Tofilovska.

Etymology: The specific epithet is used to indicate similarity to $A$. coarctata.

Ecology and distribution: Freshwater, aerophytic species, usually occurs as epiphyte on wet mosses or rocks. In the type material it is very frequent.

Notes: Achnanthes pseudocoarctata is closely related to $A$. coarctata with respect to the valve morphology. Both species share similar features, e.g. linearlanceolate valves with constriction in the mid-valve and protracted apices. The striae in A. pseudocoarctata are weakly radiate to parallel in the mid-valve, whereas in $A$. coarctata are strongly radiate throughout (compare Figs $7 \mathrm{a}-\mathrm{n}$ with Figs $1 \mathrm{a}-\mathrm{m})$. Significant differences between $A$. coarctata and $A$. pseudocoarctata can be observed in the shape of the cribrate occlusions (compare Figs 3a-f with Figs 9a-g). Areolae on the $\mathrm{R}$-valve in $A$. coarctata are occluded with cribrum which is attached by three struts to the areolae wall and perforated by 3-7 small round pores, while areolae in A. pseudocoarctata are occluded with cribrum which is attached by two struts positioned oppositely in the middle of the areola. Such position of the connecting struts gave impression that the cribrum is constricted in the middle. The cribrum in A. pseudocoarctata is perforated with 1 or 2 round pores. Additional difference can be observed in stria and areola density. The striae on $\mathrm{R}$-valve in $A$. coarctata are densely spaced (12-14 in $10 \mu \mathrm{m})$, while in A. pseudocoarctata the striae are more distantly spaced (8-10 in $10 \mu \mathrm{m})$. The striae in $A$. coarctata on $\mathrm{P}-$ valve are consisting of 12-14 areolae densely spaced, $18-20$ in $10 \mu \mathrm{m}$, while the striae in $A$. pseudocoarctata are composed of 7-9 areolae with density of $10-13$ in $10 \mu \mathrm{m}$. Differences between $A$. coarctata and $A$. pseudocoarctata can be noticed on the valve mantle (seen in the girdle view). The striae on the valve mantle on the R-valve of $A$. coarctata are composed of 4-5 areolae (BOYLE et al. 1984, fig. 3), while in A. pseudocoarctata the striae on valve mantle comprise two areolae (compare Figs $3 \mathrm{a}$, $2 \mathrm{~b}$ with Fig. 9a). This feature can be noticed with LM (compare Fig. 1n with Fig. 7o).

KRASSKE (1929, fig. 20c) described $A$. coarctata var. elliptica KRASSKE, which is characterized by linear valves with slight constriction in the mid-valve and weakly protracted and truncate apices. However, LANGE-BERTALOT et al. (1996) considered $A$. coarctata var. elliptica as part of size diminution series of $A$. coarctata sensu stricto. Achnanthes pseudocoarctata can be easily differentiated from $A$. coarctata var. elliptica by the valve size and shape of the apices. Population of A. coarcata sensu Metzeltin et al. (2005, figs 27: 3-6) is characterized by a more pronounced constriction in the mid-valve and the humps appear more angular margin instead of rounded margin in $A$. coarctata sensu stricto. This feature make it closer to the A. coarctata f. falklandica G.W.F. CARLSON (1913, p. 23, figs $3: 13,14$ ). 
Achnanthes coarctata var. constricta KRASSKE (1929, fig. 20a) represents the larger form of $A$. coarctata sens $u$ stricto and it is characterized with strong constriction in the mid-valve and more pronounced valve apices. Achnanthes coarctata var. sinaensis HustedT (1949, figs 6,7$)$ has different valve outline, linear-lanceolate without constriction in the mid-valve, that makes its easy separation from A. pseudocoarctata. Achnanthes coarctata var. elineata (LAgerstedt) O. Müller (= A. coarctatum var. elineatum LAGERSTEDT 1873, p. 49, fig. 1: 16) has wider valves $(11-13 \mu \mathrm{m})$ obtusely to truncate valve apices and higher stria density or $\mathrm{P}$ valve ( 11-12 in $10 \mu \mathrm{m})$. Achnanthes coarctata var. elineata f. antarctica Peragallo (1921, p. 14, figs 8, 9) has broadly capitate apices and higher stria density on P-valve ( 14 striae in $10 \mu \mathrm{m})$. Achnanthes distorta Peragallo (1921, p. 14, fig. 7), most probably represent teratological form of $A$. coarctata since it has strongly undulate raphe system, that is also observed in some specimens of $A$. coarctata from other populations.

Achnanthes sinaensis (HuSTEDT) LEVKov, TOFILOVSKA et C.E. Wetzel stat. nov. (Figs 11a-x, 12a-f, 13a-h, 14a-r, 15a-g)

Basionym: Achnanthes coarctata var. sinaensis HustedT 1949, Hydrobiologia 2, p. 43, figs 6, 7 .

LM observations (Figs 11a-x): Valves are linear to linear-lanceolate. Valve apices are not or weakly separated from the rest of the valve, broadly rounded to trunctate. Valve length varies from 32.5 to 43.0 $\mu \mathrm{m}$, valve width from 8.5 to $11.5 \mu \mathrm{m}$. R-valve (Figs $11 \mathrm{a}-\mathrm{k})$ : Axial area is narrow, slightly curved. Central area is broad rectangular stauros reaching the valve margin. Raphe is weakly lateral, with slightly curved raphe branches. Proximal raphe fissures are expanded into large central pores, distal fissures are unilaterally deflected. Striae are uniseriate, coarsely punctate, radiate in the mid-valve becoming strongly radiate towards the apices, $10-11$ in $10 \mu \mathrm{m}$. P-valve (Figs 111$\mathrm{x})$ : Rapheless sternum is narrow, but distinct located close the valve margin. Striae are coarse, parallel in the mid-valve, becoming strongly radiate towards the apices, $10-11$ in $10 \mu \mathrm{m}$.

SEM observations R-valve (Figs 12a-f): The frustule in girdle view is weakly flexed with a concave $\mathrm{R}-$-valve and convex P-valve (Fig. 12a). The outer surface of $\mathrm{R}$-valve is weakly flexed and weakly transapically asymmetrical (Figs 12b, d). The central area is flat without markings (Fig. 12c), while internally the central nodule is thickened and elevated from the rest of the valve (Fig. 12e). The raphe has central position and the raphe branches are weakly curved. Proximal raphe fissures are widened into tear-drop-shaped central pores (Fig. 12c). Distally, the raphe fissures are prolonged, abruptly unilaterally deflected and extending onto the valve mantle (Figs 12b, d). Internally the central endings are hooked-shaped, while the distal endings terminate with small helictoglossae (Figs 12e, f). Striae are uniseriate composed of small, round areolae. Externally, areolae have weakly recessed foramina and are occluded by cribra (Fig. 12c). The cribrum is round to elliptical shaped with narrow constriction in the middle, where it is connected by 2 (very rare 3 ) small struts to the external wall of the areola. Internally, the striae are separated by strongly thickened virgae. Areolae have round openings with noticeably recessed cribra (Fig. 12f).

P-valve (Figs 13a-h): Strongly thickened marginal ridge is present along the valve face/mantle junction (Fig. 13a). The transition from the valve face to valve mantle is abrupt (Fig. 13c). Terminal orbiculi are present on the valve mantle on each pole and on the same side as sternum (white arrows on Figs 13f, g). Externally, terminal orbiculus has elongated opening and it is occluded with a single flap of silica (Fig. 13f). Spines have not been observed. Sternum is narrow but distinct, located near the valve margin (Figs 13b, c). Internally, sternum appears as a narrow hyaline area near the valve margin (Figs 13d, g). Striae are uniseriate, coarse composed of round areolae (Fig. 13e). Areolae on $\mathrm{P}-$ valve appear larger than those on $\mathrm{R}-$ valve. Differences can be noticed also in the shape of cribra. The cribrum at the $\mathrm{R}-$-valve areolae is perforated with 3-7 small, round pores, and the cribrum is attached by 4 (rarely 5) struts to the areola wall. Striae are continuing onto the valve mantle. The areolae found on the mantle are larger; subsequently there are more perforations in cribrate pores. Externally, areolae are surrounded by strongly thickened wall (Fig. 13c). Internally, the striae are separated by strongly thickened virgae (Figs 13g, h). Areolae have round opening with clearly visible internal cribra structure (Fig. 13h).

Ecology and distribution: Freshwater, aerophytic species, usually occurs as epiphyte on wet mosses or rocks. In the samples from wet rock on Osogovo Mountain this species is very frequent.

Notes: Simonsen (1987, p. 351, fig. 537: 1-5) made formal typification of $A$. coarctata var. sinaensis and proposed the types using BRM Ma4/42 (as lectotype) and Ma4/49 (as isolectotype). Both slides have been observed in this study and the most representative valves found on the slides are depicted on Figs 14a-r. Additionally, the type material (AS1169) was observed with SEM, and observed specimens are illustrated on Figs $15 \mathrm{a}-\mathrm{g}$. The population of Achnanthes sinaensis from Osogovo Mountain resembles A. coarctata var. sinaensis HusTEDT (1949, figs 6, 7) with respect to valve appearance. However, differences can be seen in few morphological features. Achnanthes sinaensis from the type locality has linear-lanceolate valves with distinctly protracted apices (Figs 14a-h, k-r), whereas the valves from Osogovo Mountain have more linear outline with weakly to not protracted apices. Additionally, the valves of the type population are wider $(10.5-12.5 \mu \mathrm{m})$ than the population from 
Osogovo Mountain. However, other morphological and numerical features are overlapping. Moreover, the SEM observations of the type material (Figs 15a-g) do not reveal any significant difference between these two populations. Achnanthes spec. cf. coarctata sensu Metzeltin et al. (2005, figs 32: 10-13) has similar valve outline as population from Osogovo Mt. (linearlanceolate with weakly rostrate to subcapitate apices) and valve size (length $30-33 \mu \mathrm{m}$, width $6.5-8 \mu \mathrm{m}$ ), but it differs by the sublateral position of the rapheless sternum, whereas in A. sinaensis is marginal. Also $A$. spec. cf. coarctata sensu Metzeltin et al. (2005, figs 10-13) has higher stria density (13-16 in $10 \mu \mathrm{m})$ than A. sinaensis.

Achnanthes prominula Levkov et Tofilovska sp. nov. (Figs 16a-ac, 17a-f, 18a-g)

\section{Description}

LM observations (Figs 16a-ac): Valves are linearlanceolate in larger specimens to elliptic-lanceolate in smaller specimens. Valve length varies from 18.5 to $43.0 \mu \mathrm{m}$, valve width is $8.5-10.5 \mu \mathrm{m}$. $\mathrm{R}$-valve (Figs $16 \mathrm{a}-\mathrm{n})$ : Axial area is narrow, central area is variable in shape and size, narrow to wide and rectangular to panduriform, stauros reaching the valve margin. In some specimens central area is bordered by strongly shortened central striae (Figs 16e, f, n). Raphe is weakly lateral, with slightly curved raphe branches. Proximal raphe fissures are slightly expanded into central pores; distal fissures are strongly curved in the same direction almost till the end of mantle. Striae are uniseriate, coarsely punctate, weakly radiate in the mid-valve becoming strongly radiate towards the apices, $11-12$ in $10 \mu \mathrm{m}$ on raphe valve. P-valve (Figs 16o-ac): Rapheless sternum is narrow, but distinct, located close to the valve margin and following the line of the margin. Striae are coarse, parallel in the mid-valve, becoming radiate towards the apices and strongly curved at the apices, $10-12$ in $10 \mu \mathrm{m}$.

SEM observations R-valve (Figs 17a-f): The Rvalve is weakly flexed and concave. Externally, the central area is flat without markings almost rectangular (Figs 17a-c), while internally it is rectangular and thickened (Figs 17e, f). A small depression is present in the middle of the central nodule (arrow in Fig. 17f). The raphe has central position and the raphe branches are weakly curved. Proximal raphe fissures externally are widened into tear-drop-shaped central pores and slightly unilaterally deflected. Distally, the raphe fissures are strongly curved in the opposite direction of the proximal fissures and continuing onto valve mantle (Fig. 17b, d). Internally the central endings are hooked-shaped (Fig. 17f), while the distal endings terminate with small helictoglossae (Fig. 17e). Striae are uniseriate, composed of small, round areolae. Externally, areolae are occluded with cribra and have weakly recessed foramina. The cribrum is round to elliptical and it is connected with usually four small (rarely with two or three) struts to the external wall of the areola (Figs 17c,d). The cribrum is perforated with 7-9 cribrate pores. The size of the areolae increases towards the apices. Internally, the striae are separated by thickened virgae, areolae have round openings with noticeably recessed cribra (Figs 17e, f).

P-valve (Figs 18a-g): The external surface of the $\mathrm{P}-$ valve is flexed with convex mid-valve (Figs 18b, d). Strongly thickened marginal ridge is present along the valve face/mantle junction (Figs 18a, d). The marginal ridge is more pronounced at the apices. The transition from the valve face to valve mantle is abrupt (Fig. 18c). Spines have not been observed. Terminal orbiculi are present on the valve mantle on each pole on the same side as sternum (white arrows on Fig. 18b). Externally, terminal orbiculus has elongated opening and it is occluded with a single flap of silica (white arrow on Fig. 18e). Occlusion of the terminal orbiculus has different structure than the cribrum of the areolae (Fig. 18e). The rapheless sternum is narrow but distinct, located near the valve margin. Internally, sternum appears as a narrow hyaline area near the valve margin (Fig. 18f). Striae are uniseriate composed of round areolae. The areolae on $\mathrm{P}-$-valve are smaller than the areolae on $\mathrm{R}-$ valve $(0.20-0.40 \mu \mathrm{m}$ vs. $0.45-$ $0.65 \mu \mathrm{m})$ Also difference between cribrate occlusion on areolae on $\mathrm{P}-$ and $\mathrm{R}$-valve can be noticed. Cribra on $\mathrm{P}-$ valve is round, perforated with many small round pores. Cribrum is attached to the pore wall with many small struts. Striae continued on the valve mantle. The areolae on the valve mantle, near the marginal ridge are larger, surrounded by strongly thickened wall (Figs $18 \mathrm{c}, \mathrm{e})$. Externally, the areolae are occluded by cribra. Internally, the striae are separated by strongly thickened virgae (Fig. 18f). Areolae have round opening with clearly visible internal cribra structure (Fig. 18g).

Holotype (designated here): Slide 006647/C in MKDNC, specimen representing the holotype is Fig. $16 f$.

Isotypes: Slide BRM ZU9/29, BM 101684.

Type locality: Mountain Jakupica, near river Babuna, cave Peshti, Macedonia, Lat.: 4140'11.38’N. Long.: 2146'55.65'E.

Type material: Wet mosses and mud, collection date: 21.04.2012. Accession No. MKDNC 006647. Collected by S. Tofilovska.

Etymology: The specific epithet is used to indicate the possession of prominent characters that make easy differentiation of this species.

Ecology and distribution: Freshwater, aerophytic species, usually occurs as epiphyte on wet mosses or rocks. In the type material it is very frequent.

Notes: Achnanthes prominula resembles $A$. intermedia KüTZING (1833, p. 576, fig. 16: 56) (here as Figs 19au) with respect to the valve outline. Both species have lanceolate to elliptic-lanceolate outline with narrowly rounded apices. The lectotypification and LM and 
SEM observations of the type material of $A$. intermedia have been made by TOYODA \& Williams (2004). Main differences between $A$. prominula and A. intermedia [= A. brevipes var. intermedia (KüTZING) CLEVE] can be observed in the position of the rapheless sternum on $\mathrm{P}$-valve, valve size and stria density. The rapheless sternum in A. intermedia is slightly lateral, opposite to $A$. prominula where the rapheless sternum is located close to the valve margin and following the line of the margin. The valve width of $A$. intermedia varies from 9 to $15 \mu \mathrm{m}$, whereas in $A$. prominula the valve width is 8.5-10.5 $\mu \mathrm{m}$. The valves from both species with same size can be easily differentiated by the stria density and areolae size. The striae in smaller specimens of $A$. intermedia are more distantly spaced (8-10 in $10 \mu \mathrm{m})$ and composed of three large areolae, opposite to 12 13 striae in $10 \mu \mathrm{m}$ in $A$. prominula composed of five small areolae. With SEM, differences between these two species can be seen in the areolae shape, cribrate occlusions and virgae thickness on the $\mathrm{P}$-valve. The areolae in A. intermedia (Toyoda \& Williams 2004, fig. 19) are square occluded with cribra connected to the areola wall by four small struts. The virgae are strongly thickened and more pronounced in A. intermedia, and are interrupted by the raphe less sternum.

Achnanthes prominula has a similar valve outline to Achnanthes pachypus KüTzING, as illustrated by Cox $(2006$, figs 8,9$)$ from type slides BM 18457 , but from the latter it can be easily differentiated by the position of the rapheless sternum (lateral) and the stria density (5-7 in $10 \mu \mathrm{m}$ in A. pachypus). Achnanthes subsessilis KützInG (1833, fig. 55; Hendey 1951, figs 15: 9,10 ) has valve with linear outline, almost parallel margins and around $7 \mu \mathrm{m}$ wide. Internally the central area is clearly panduriform and elevated from the rest of the valve (BLunN \& Evans 1981, fig. 4). Achnanthes subsessilis var. multiarticulata KüTZING (as illustrated by Cox 2006, figs 8, 9 from type slide BM 18469) has comparable stria density as A. prominula, but it possesses wider valves and lateral position of the sternum. Lectotype valves of $A$. coarctata var. elliptica KrASSKE (1929, fig. 20c), illustrated in LANGEBERTALOT et al. (1996, pl. 7, figs 4, 5) represent smaller specimens of $A$. coarctata. Lectotype valves have linear outline with slight constriction in the mid-valve and slightly protracted and truncate apices.

Achnanthes prominula resembles $A$. secretitaeniata $\mathrm{K}$. TOYODA et J. TANAKA in TOYODA et al. (2009, figs 1-24) with respect to the valve outline (linear-lanceolate with narrowly rounded apices), valve size (33-41 $\mu \mathrm{m}$ long, 10-11 $\mu \mathrm{m}$ wide) and stria density $(10-11$ in $10 \mu \mathrm{m})$. Differences between these two species can be observed in the shape of the rapheless sternum and presence of the terminal orbiculi. Achnanthes parvula KüTZING has also lateral position of the rapheless sternum and panduriform central area which is strongly widened near the valve margin (McIntiRe \& Reimer 1974, figs 4a, b). The valves of $A$. longboardia SHERwOOd et Lowe (in Lowe et al. 2009, p. 329, figs 1-8) have rhombic-lanceolate outline and higher stria density $(\mathrm{R}-\mathrm{valve}=13-15 / 10$ $\mu \mathrm{m} ; \mathrm{P}-$ valve $=12-14 / 10 \mu \mathrm{m})$. Additionally, terminal orbiculus is absent in A. longboardia, while it is present in A. prominula.

Achnanthes muelleri G.W.F. CARLSON (1913, p. 23, figs 3: 5-7) is characterized by rhombiclanceolate valves even in the smaller specimens in the size diminution series (VAN DE VIJVER et al. 2002). Additionally, A. muelleri has an elliptical central area, while A. prominula has rectangular to panduriform central area. The striae in $A$. muelleri are coarser composed of large, almost rectangular areolae ( $\mathrm{LE} \mathrm{COHU}$ 2005 , figs 10,13). However, some valves of $A$. muelleri depicted in Le CoHu (2005, figs 2, 3, 6) probably do not belong to $A$. muelleri, having smaller valves with higher stria density. Achnanthes taylorensis KellogG, Stuiver, Kellogg et Denton (in Kellogg et al. 1980, pp. 174, 175, figs $1: 3,4 ; 2: 1,2)$ is another freshwater species found in Antarctic region. Achnanthes prominula can be differentiated from A. taylorensis by the valve shape, which in A. taylorensis is linearlanceolate with broadly rounded apices. Additionally, the striae in A. taylorensis on $\mathrm{P}$-valve are strongly radiate throughout the whole valve length, as opposed to parallel striae in the mid-valve at $A$. prominula. Achnanthes mauiensis Lowe et SHERwoOd (in Lowe et al. 2009, p. 330, figs 9-19) has different valve shape (linear, slightly tumid in the mid-valve) and distinctly rostrate apices, which make easy separation from $A$. prominula. Achnanthes muscorum Peragallo (1921, p. 14, fig. 1: 2, 3) has rhombic-lanceolate valves with small, irregularly-shaped central area bordered with 2-3 shortened central striae. These features make easy differentiation of $A$. prominula and A. muscorum.

\section{Acknowledgments}

This study was founded by the Alexander von Humboldt Foundation and SYNTHESYS program. We would like to express our gratitude to Dr. Kensuke Toyoda, National Research Institute of Fisheries and Environment of Inland Sea, Fisheries Research Agency, Hiroshima and Dr. David M. Williams, Department of Botany, The Natural History Museum, London for useful discussions during preparation of this study. We are grateful to Dr. Bart Van de Vijver, Department of Bryophyta \& Thallophyta, National Botanic Garden of Belgium, Meise and Mrs. Friedel Hinz, The Friedrich Hustedt Diatom Study Centre, Bremerhaven for loan of the type materials for $A$. coarctata and $A$. coarctata var. sinaensis, respectively. Our thanks also go to Mrs. Danijela Mitić-Kopanja, Institute of Biology, Faculty of Natural Science in Skopje, for technical support.

\section{REFERENCES}

BlunN, G.W. \& Evans, L.V. (1981): Microscopical observations on Achnanthes subsessilis, with particular reference to stalk formation. - Botanica Marina 24: 193-199.

Bory de SaInT Vincent, J.B.M. and coll. (1822): Dictionnaire 
Classique d'Histoire Naturelle, Tome premier. - 604 pp. Baudouin Frères, libraires-éditeurs, Paris.

Boyer, C.S. (1927): Synopsis of North American diatomaceae.Part II.- Naviculatae, Surirellatae. Proceedings of the Academy of Natural Sciences of Philadelphia 79 supplement: 228-583.

Boyle J.A.; Pickett-Heaps, J.D. \& Czarnecki, D.B. (1984): Valve morphogenesis in the pennate diatom Achnanthes coarctata. - Journal of Phycology 20: 563-573.

Bukhtiyarova, L. \& Round, F.E. (1996): Revision of the genus Achnanthes sensu lato. Psammothidium, a new genus based on A. marginulatum. - Diatom Research 11: $1-30$.

CARLSON, G.W.F. (1913): Süsswasseralgen aus der Antarktis, Südgeorgien und den Falkland Inseln. Wissenschaftliche Ergebnisse der Schwedischen Südpolar-Expedition 1901-1903 unter Leitung von Dr. Otto Nordenskjöld. - Lithographisches Institut des Generalstabs, Band 4 (Lieferung 14). - 94 pp. Kungl. Boktryckeriett, P.A. Norstedt \& Söner, Stockholm.

Cleve, P.T. \& Grunow, A. (1880): Beiträge zur Kenntniss der Arctischen Diatomeen. - Kongliga SvenskaVetenskaps-Akademiens Handlingar 17: 121 pp., 7 pls.

Cox, E.J. (2006): Achnanthes sensu stricto belongs with genera of the Mastogloiales rather than with other monoraphid diatoms (Bacillariophyta). - European Journal of Phycology 41: 67-81.

GANDHI, H.P. (1960): VI. - Some new diatoms from Jog-Falls (Mysore State). - Journal of the Royal Microscopical Society 79: 81-87.

GandHI, H.P. (1966): The fresh-water diatomflora of JogFalls, Mysore State. - Nova Hedwigia 11: 89-197.

Gonzalves, E.A. \& Gandhi, H.P. (1952): A systematic account of the diatoms of Bombay and Salsette. Part I. Centrales: Sub-order - Discineae and Pennales: Sub-orders - Araphidineae, Raphidioidineae, Monoraphidineae and Biraphidineae. - Journal of the Indian Botanical Society 31: 117-151.

Hendey, N.I. (1951): Littoral diatoms of Chichester Harbour with special reference to fouling. - Journal of the Royal Microscopical Society 71: 1-86.

Hoffmann, L. (2002): Caves and other low-light environments: Aerophitic photoautotrophic microorganisms. - In: BitTon, G. (ed.): Encyclopedia of Environmental Microbiology. - pp. 832-843, New York, John Wiley \& Sons.

Hustedt, F. (1949): Diatomeen von der Sinai-Halbinsel und aus dem Libanon-Gebiet. - Hydrobiologia 2: 24-55.

JURILJ, A. (1954): Flora and vegetation of diatoms from Ohrid Lake. - Prirodoslovna Istrazivanja 26: 99-190.

Kellogg, D.E.; Stuiver, M.; KellogG, T.B. \& Denton, G.H. (1980): Non-marine diatoms from late Wisconsin perched deltas in Taylor Valley, Antarctica. Palaeogeography, Palaeoclimatology, Palaeoecology 30: $157-189$.

Krammer, K. \& LANGe-Bertalot, H. (2004): Bacillariophyceae 4. Teil: Achnanthaceae, Kritische Ergänzungen zu Achnanthes s. 1., Navicula s. str., Gomphonema. Gesamtliteraturverzeichnis Teil 1-4. - In: Ettl, H.; Gärtner, G.; Gerloff, J.; Heynig, H. \& Mollenhauer, D. (eds): Süsswasserflora von Mitteleuropa 2/4. - 468 pp., 93 pls., Spektrum
Akademischer Verlag, Heidelberg.

KRASSKE, G. (1929): Beiträge zur Kenntnis der Diatomeenflora Sachsens. - Botanisches Archiv 27: 348-380, 1 pl.

KützING, F.T. (1833): Synopsis Diatomearum oder Versuch einer systematischen Zusammenstellung der Diatomeen. - Linnaea 8: 529-620, pls. 13-19.

LAGERSTEdT, N.G.W. (1873) Sötvattens-Diatomaceer från Spetsbergen och Beeren Eiland. - Bihang till Kongliga Svenska Vetenskaps-Akademiens Handlingar 1: 1-52, 2 pls.

Lange-Bertalot, H.; Külbs, K.; Lauser, T.; NörPelSchempp, M. \& Willmann, M. (1996): Diatom taxa introduced by Georg Krasske. Documentation and revision - Dokumentation und Revision der von Georg Krasske beschriebenen Diatomeen-Taxa. Iconographia Diatomologica 3: 1-358.

Le Cohu, R. (2005): Révision des principales espèces dulçaquicoles d'Achnanthales (Bacillariophyta) des îles subantarctiques de Kerguelen. - Algological Studies 116: 79-114.

Levkov, Z.; Krstic, S.; Metzeltin, D. \& Nakov, T. (2007): Diatoms of Lakes Prespa and Ohrid (Macedonia). Iconographia Diatomologica 16: 1-603.

Lowe, R.L.; SHeRwood, A.R. \& Ress, J.A. (2009): Freshwater species of Achnanthes Bory from Hawaii. - Diatom Research 24: 327-340.

MCIntiRe, C.D. \& Reimer, C.W. (1974): Some marine and brackish-water Achnanthes from Yaquina Estuary, Oregon (U.S.A.). - Botanica Marina 17: 164-175.

Metzeltin, D.; Lange-Bertalot, H. \& García-Rodríguez, F. (2005). Diatoms of Uruguay. Compared with other taxa from South America and elsewhere. Iconographica Diatomologica 15: 1-736.

Peragallo, M. (1921): Première partie. Diatomées d'eau douce. Deuxième Expédition Antarctique Française (1908-1910) commandée par le $\mathrm{D}^{\mathrm{r}}$ Jean Charcot. Sciences Naturelles : Documents Scientifiques. Botanique. - pp. 1-38, 1 pl., Masson et Cie, Paris.

Petrovska, L. \& Stojanov, P. (1975): Algal vegetation of rocks in Macedonia. - Annual Biology, PMF, Skopje. 27-28: 161-168.

PoulíčKovÁ, A. \& Hašler, P. (2007): Aerophytic diatoms from caves in central Moravia (Czech Republic). Preslia 79: 185-204.

Round, F.E. \& BAsson, P.W. (1997). A new monoraphid diatom genus (Pogoneis) from Bahrain and the transfer of previously described species $A$. hungarica and A. taeniata to new genera. - Diatom Research 12: $71-81$.

Round, F.E. \& BukhtiYarova, L. (1996). Four new genera based on Achnanthes (Achnanthidium) together with a re-definition of Achnanthidium. - Diatom Research 11: 345-361.

Round, F.E.; Crawford, R.M. \& Mann, D.G. (1990): The diatoms. Biology and morphology of the genera. 747 pp., Cambridge University Press, Cambridge.

Simonsen, R. (1987): Atlas and Catalogue of the diatom types of Friedrich Hustedt. Volumes 1-3. - 525 pp., 772 pls., J. Cramer, Berlin, Stuttgart.

SMITH, W. (1855): Notes of an excursion to the south of France and the Auvergne in search of Diatomaceae. - Annals and Magazine of Natural History ( $2 n$ ser.): 15: $1-9$.

Toyoda, K. \& Williams, D.M. (2004): Description of Achnanthes Bory (Bacillariophyceae) based 

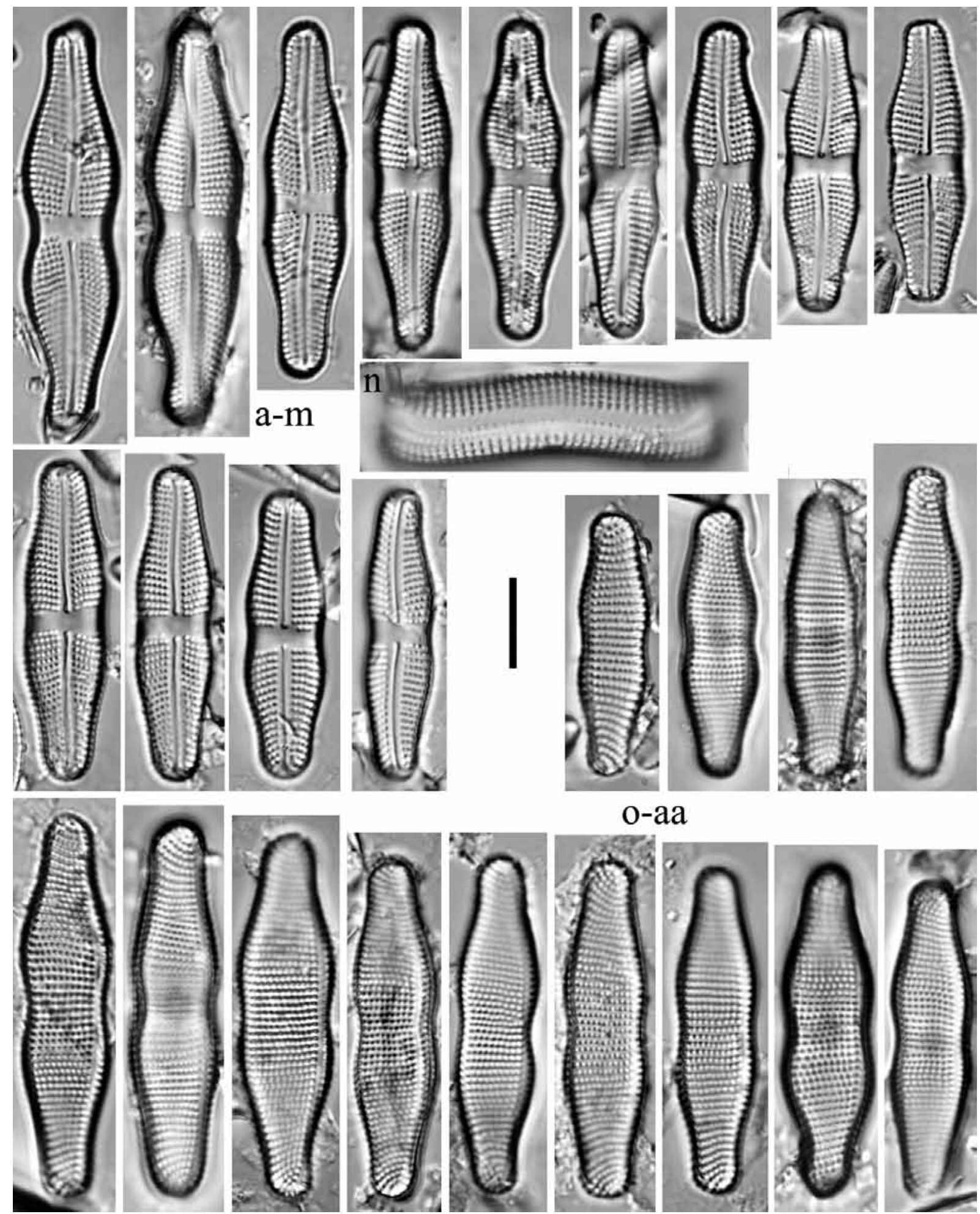

Figs 1a-aa. Achnanthes coarctata, LM, Osogovo Mountain, Macedonia: (1a-m) size diminution series of the R-valve, (1n) frustule in girdle view, (1o-aa) size diminution series of the $\mathrm{P}-\mathrm{valve}$. Scale bar $10 \mu \mathrm{m}$. 

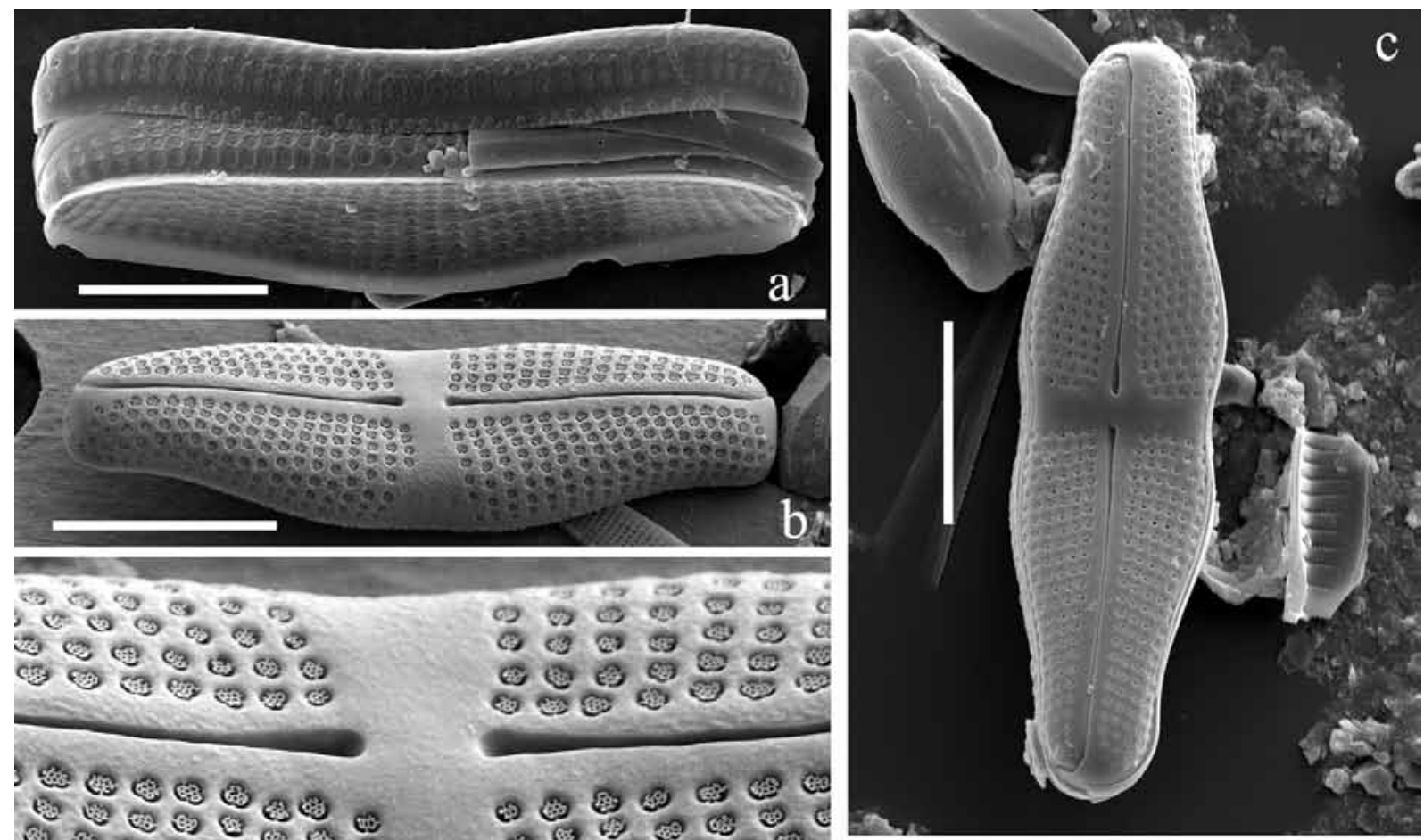

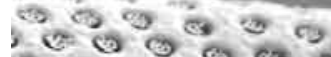

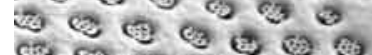

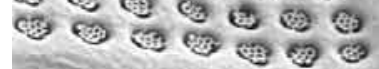
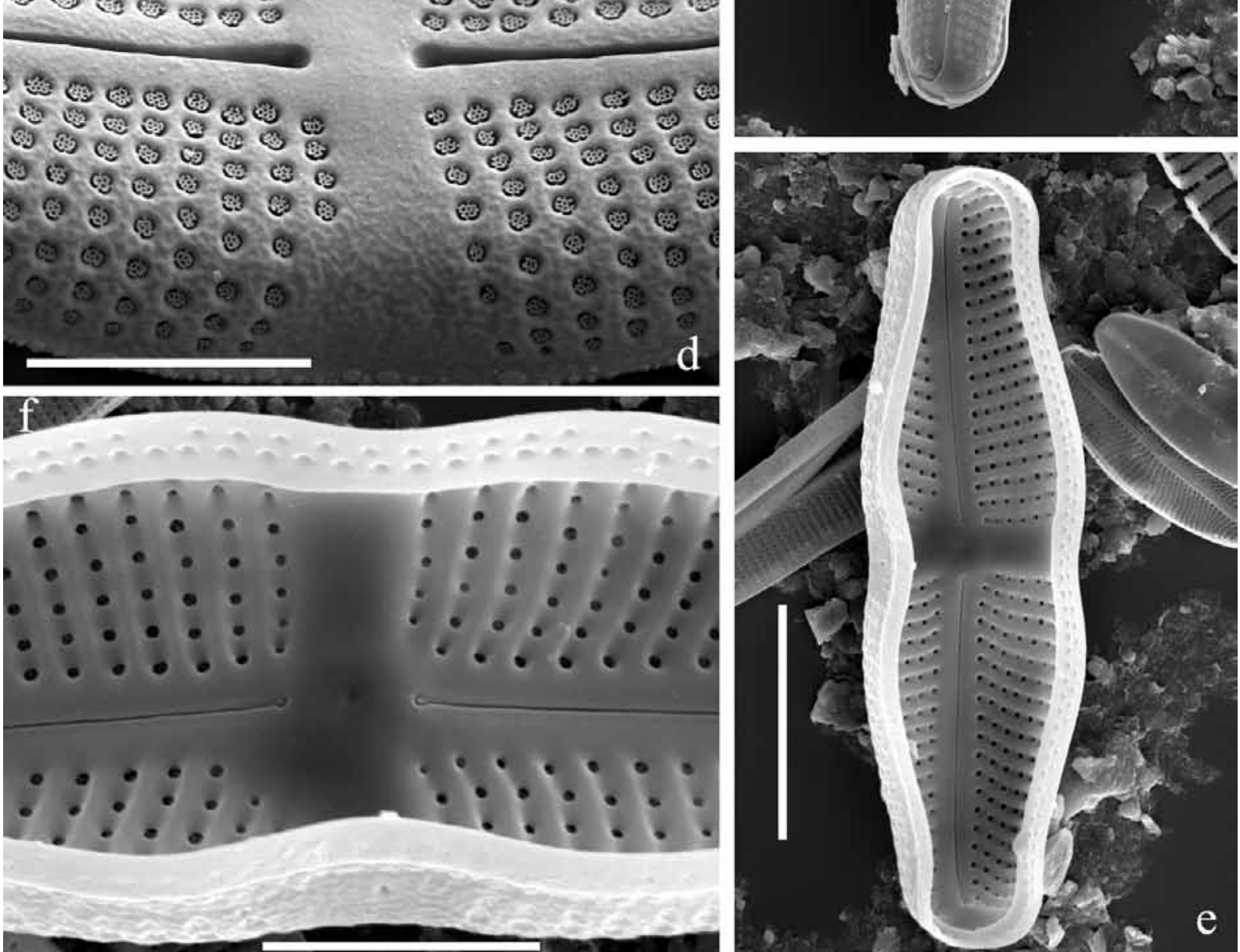

Figs 2a-f. Achnanthes coarctata, SEM, Osogovo Mountain, Macedonia: R-valve and frustule: (2a) frustule in girdle view, (2b, 2c) external valve view, (2d) detailed view of the mid-valve, (2e) internal valve view, (2f) detailed view of the mid-valve. Scale bar $10 \mu \mathrm{m}$ (Figs $2 \mathrm{a}-\mathrm{c}, 2 \mathrm{e})$, $5 \mu \mathrm{m}$ (Figs 2d, 2f). 

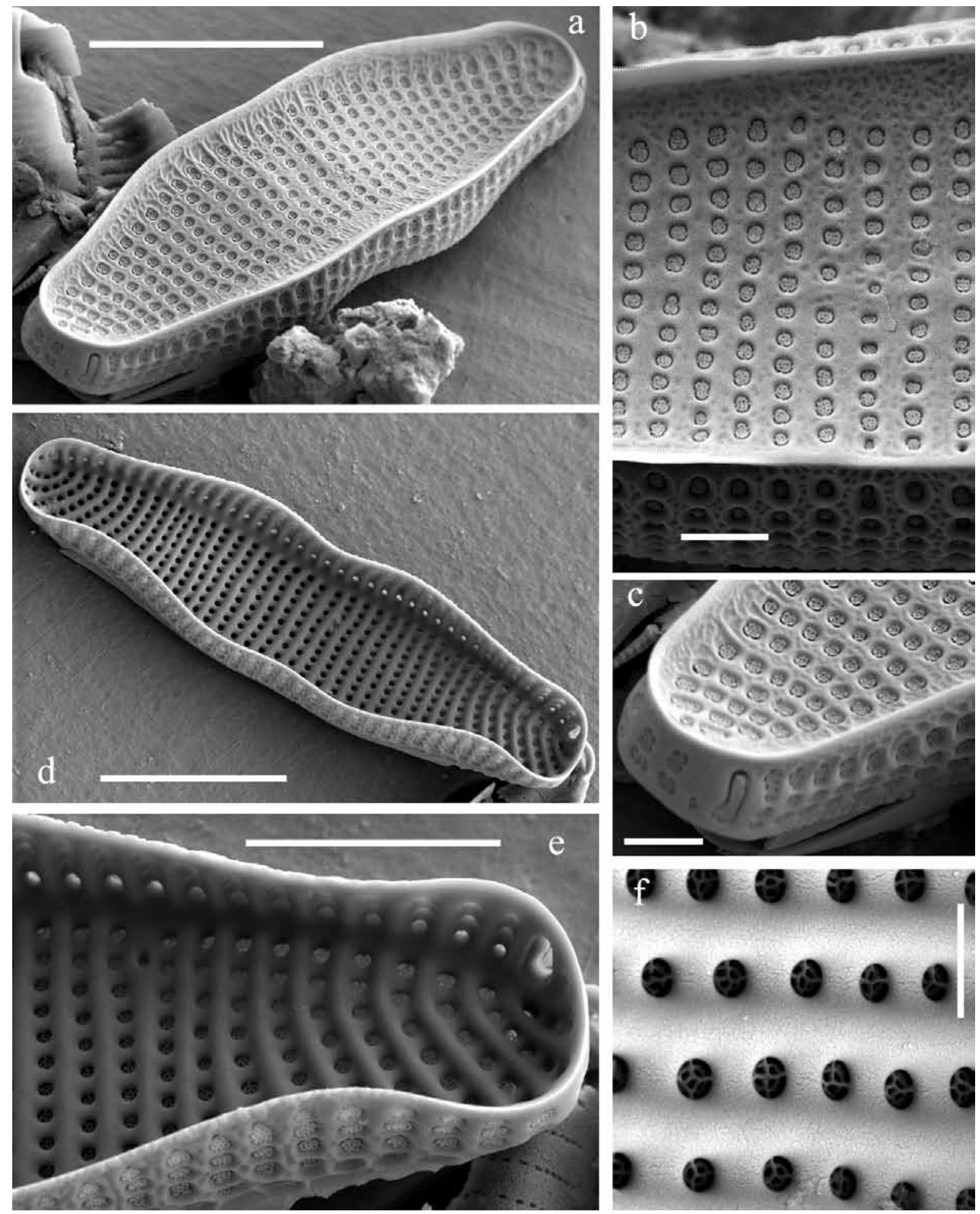

Figs 3a-f. Achnanthes coarctata, SEM, Osogovo Mountain, Macedonia: P-valve and frustule: (3a) external valve view, (3b) detailed view of the mid-valve, (3c) detailed view of the valve apex, (3d) internal valve view, (3e) internal view of the valve apex, (3f) detail of the mid-valve showing the areolae apertures and costae. Scale bar $10 \mu \mathrm{m}$ (Figs 3a, 3d), $5 \mu \mathrm{m}$ (3e), $2 \mu \mathrm{m}$ (3b, 3c), $1 \mu \mathrm{m}$ (3f). 

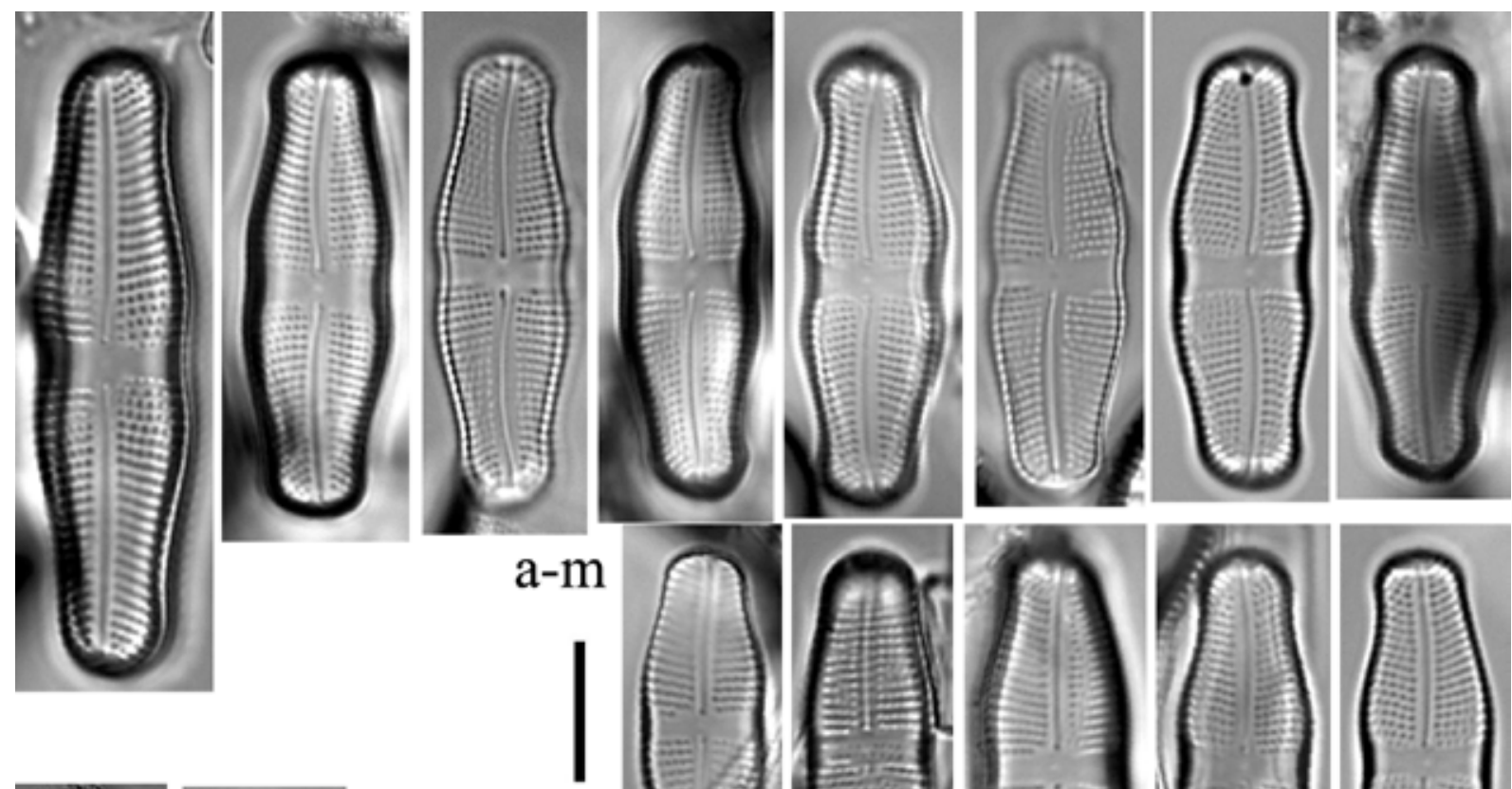

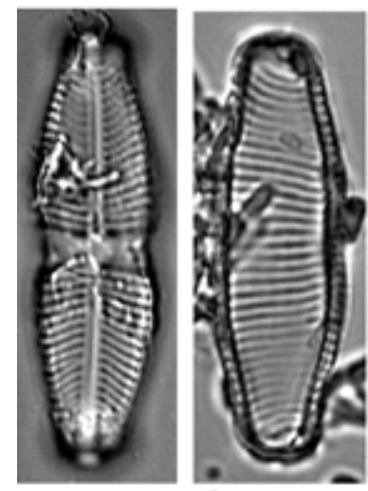

$\mathrm{aa}-\mathrm{ab}$
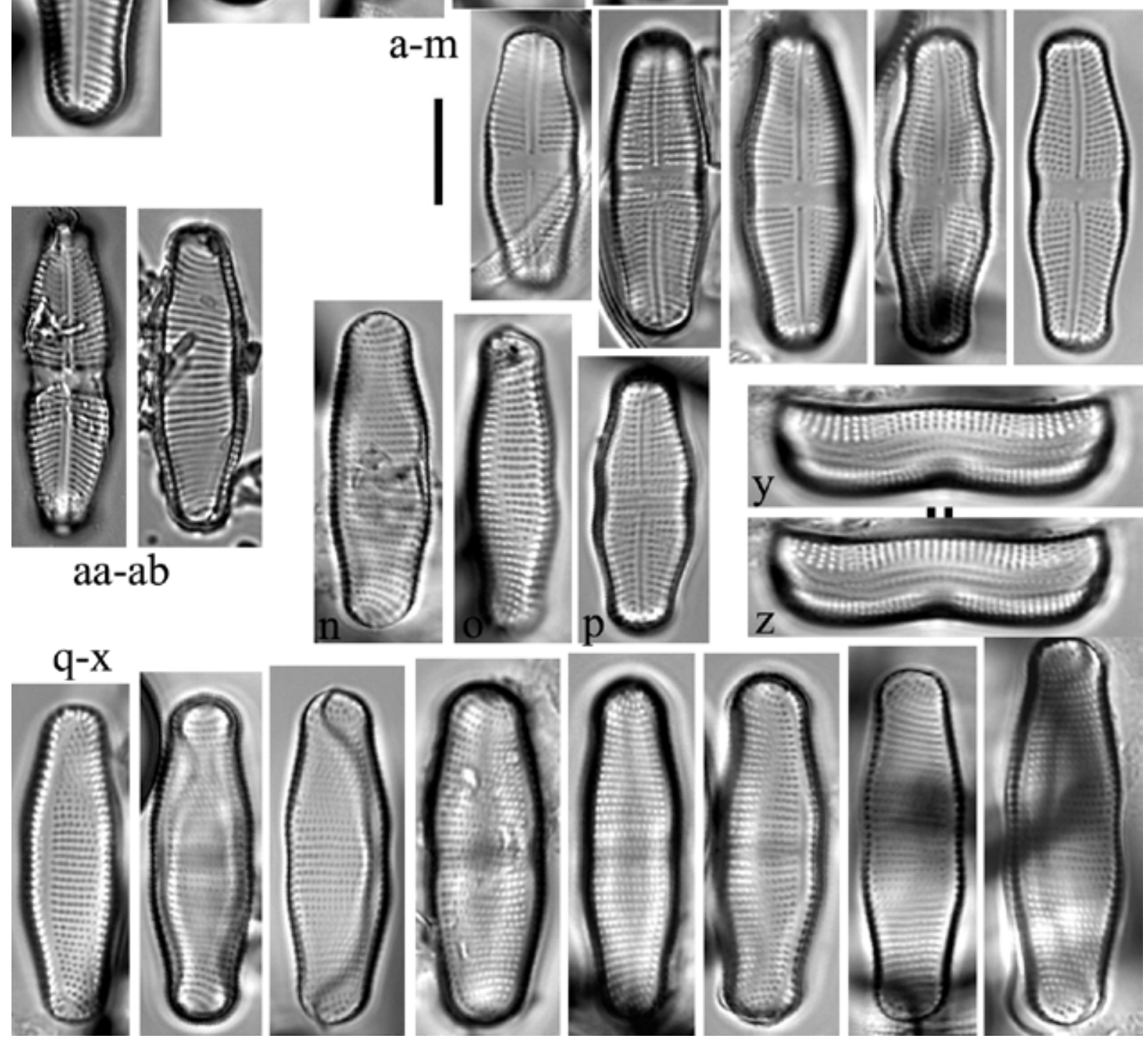

Figs 4a-ab. Achnanthes coarctata, LM, syntype populations. Figs 4a-z. Cave near Royat, France: (4a-m) size diminution series of the R-valve, $(4 n-x)$ size diminution series of the $\mathrm{P}-$ valve, (4y-z) frustule in girdle view. Figs 4aa-ab. Falaise, France: (4aa) R-valve, (4ab) P-valve. Scale bar $10 \mu \mathrm{m}$. 


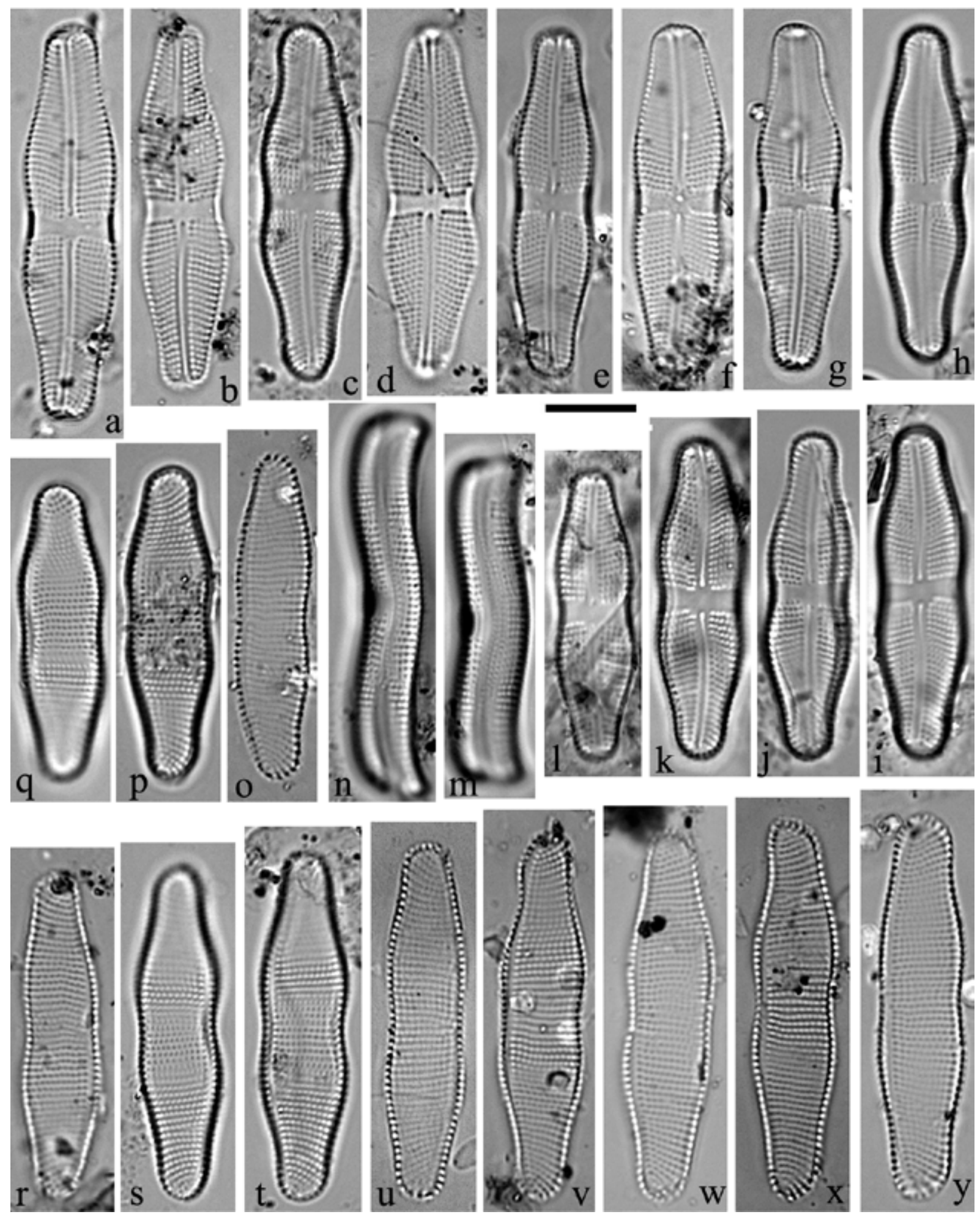

Figs 5a-y. Achnanthes coarctata, LM, Grassmere, Westmoreland, United Kingdom: (5a-1) size diminution series of the R-valve, (5m-n) frustule in girdle view, (5o-y) size diminution series of the P-valve. Scale bar $10 \mu \mathrm{m}$. 

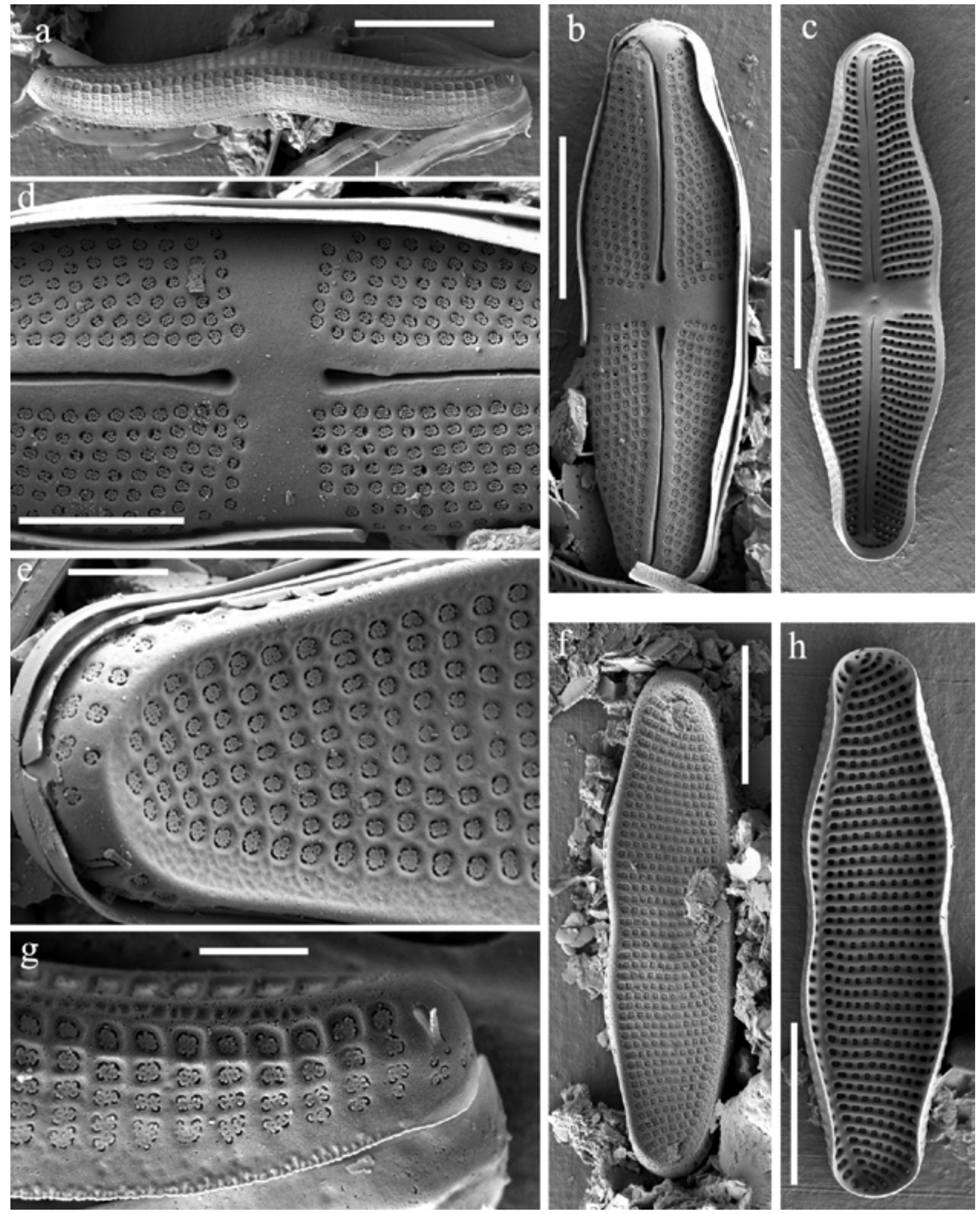

Figs 6a-h. Achnanthes coarctata, SEM, Grassmere, Westmoreland, United Kingdom, R- and P-valve: (6a) P-valve in girdle view, (6b) external view of the R-valve, (6c) internal view of the R-valve; (6d) detailed view of the mid-valve of the R-valve, (6e, g) detailed view of the valve apex of the P-valve, (6f) external view of the P-valve, (6h) internal view of the P-valve. Scale bar $10 \mu \mathrm{m}$ (Figs $6 \mathrm{a}-\mathrm{c}, \mathrm{f}, \mathrm{h}$ ), $5 \mu \mathrm{m}$ (Fig. 6d), $2 \mu \mathrm{m}(6 \mathrm{e}, \mathrm{g})$. 


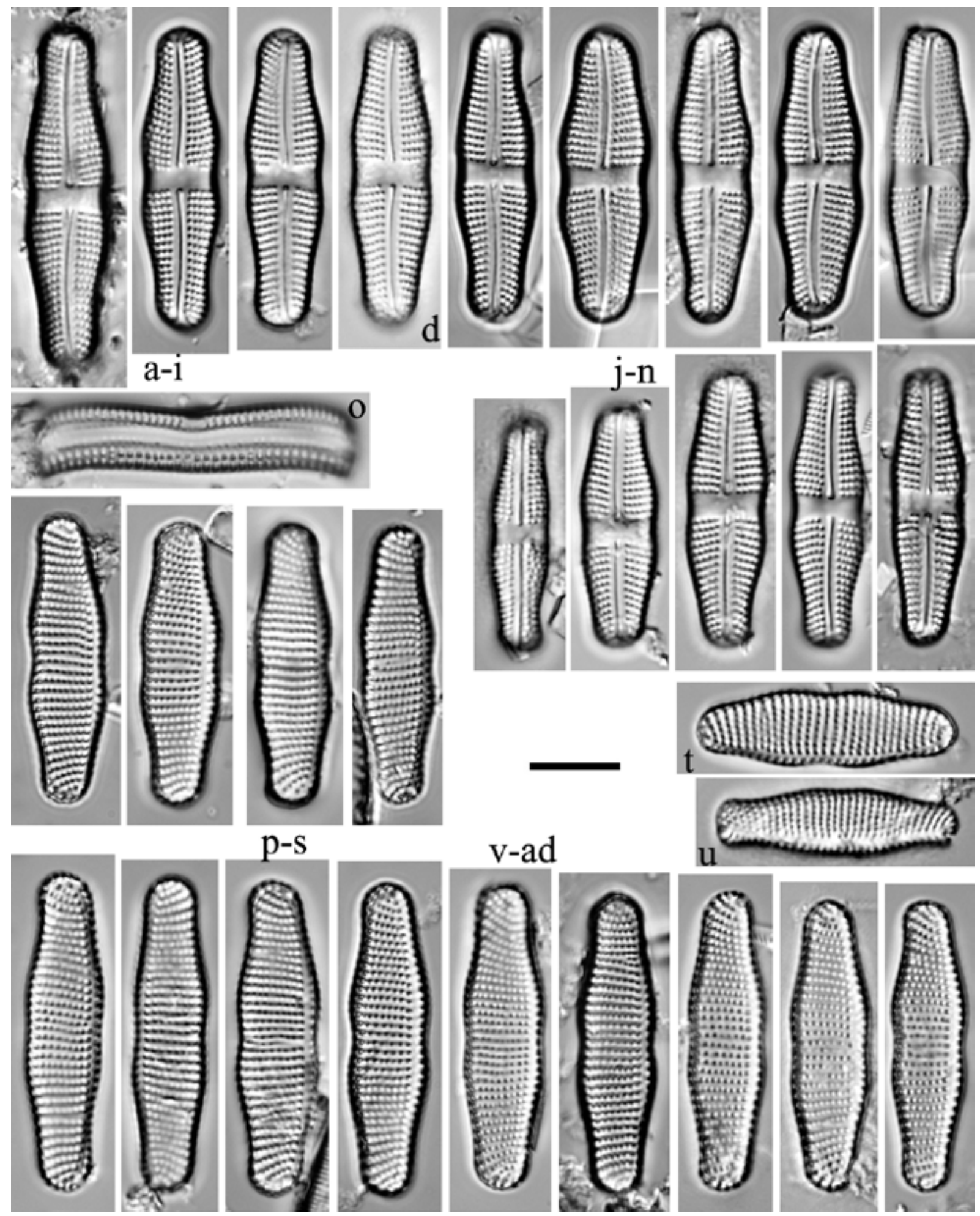

Figs 7a-ad. Achnanthes pseudocoarctata sp. nov. LM, Cave Peshti, Macedonia: (7a-n) size diminution series of the R-valve, (7o) frustule in girdle view, (7p-ad) size diminution series of the P-valve. Fig. $7 \mathrm{~d}$ represents the holotype. Scale bar $10 \mu \mathrm{m}$. 

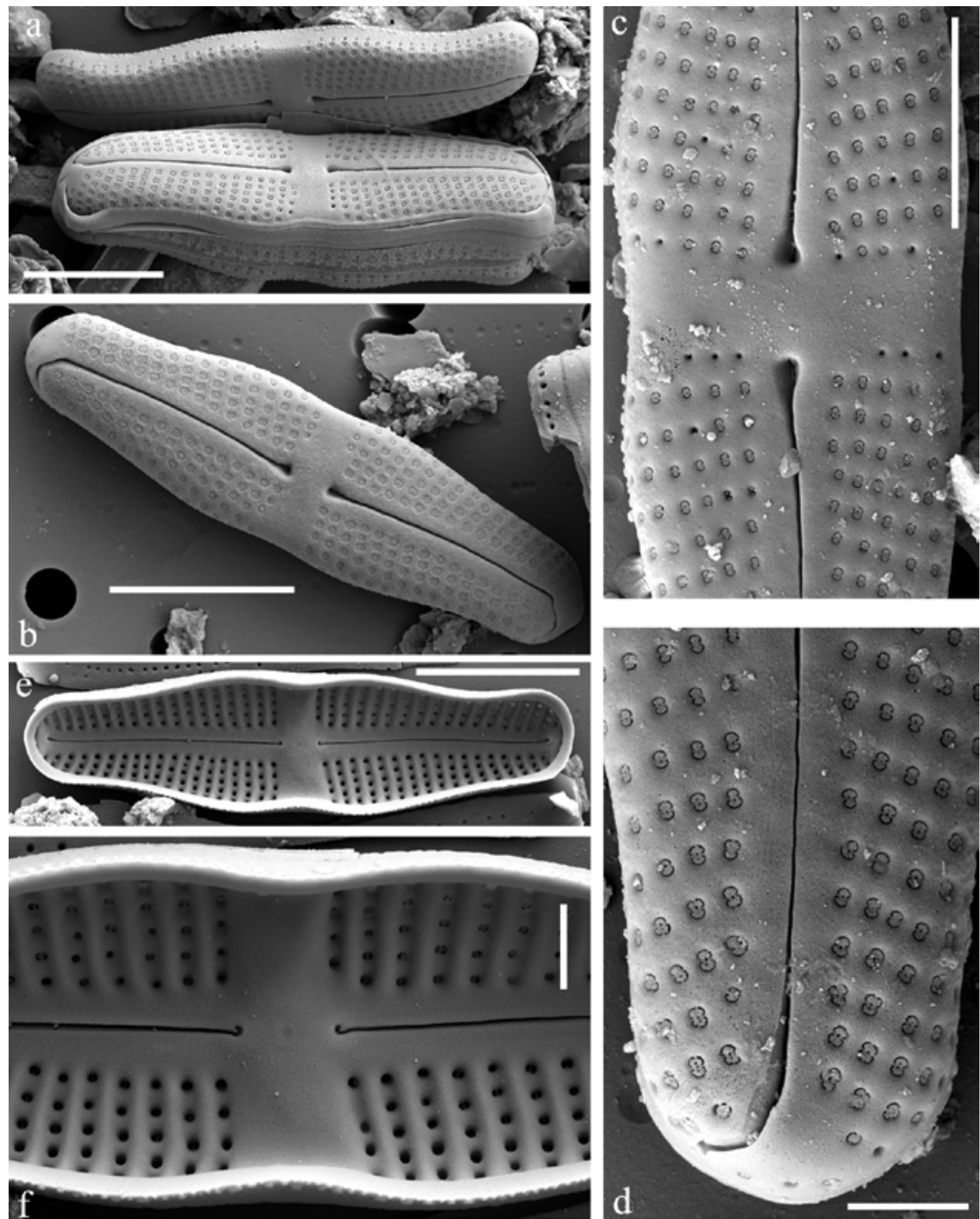

Figs 8a-f. Achnanthes pseudocoarctata sp. nov. SEM, Cave Peshti, Macedonia: R-valve and frustule: (8a, b) external valve view, (8c) detailed view of the mid-valve, (8d) detailed view of the valve apex, (8e) internal valve view, (8f) detailed view of the mid-valve. Scale bar $10 \mu \mathrm{m}$ (Figs 8a, b, e), $5 \mu \mathrm{m}$ (Fig. 8c), $2 \mu \mathrm{m}$ (Figs 8d, f). 

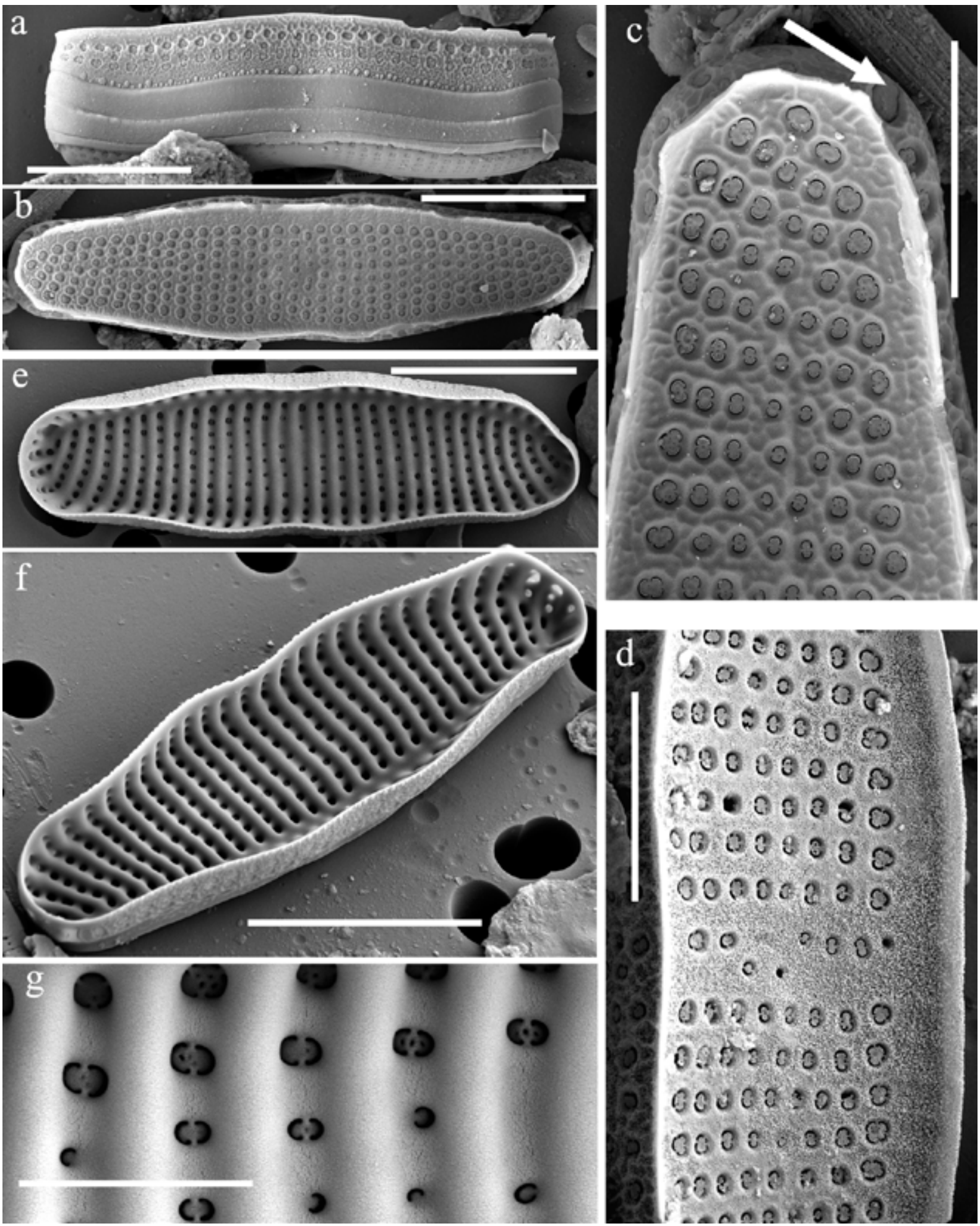

Figs 9a-g. Achnanthes pseudocoarctata sp. nov. SEM, Cave Peshti, Macedonia: P-valve and frustule: (9a) frustule in girdle view, (9b) external valve view, (9c) detailed view of the valve apex, (9d) detailed view of the mid-valve, $(9 \mathrm{e}, \mathrm{f})$ internal valve view, $(9 \mathrm{~g})$ detail of the mid-valve showing the areolae apertures and costae. Scale bar $10 \mu \mathrm{m}$ (Figs 9a, b, e, f), $5 \mu \mathrm{m}(9 \mathrm{c}, \mathrm{d}), 2 \mu \mathrm{m}(9 \mathrm{~g})$. 

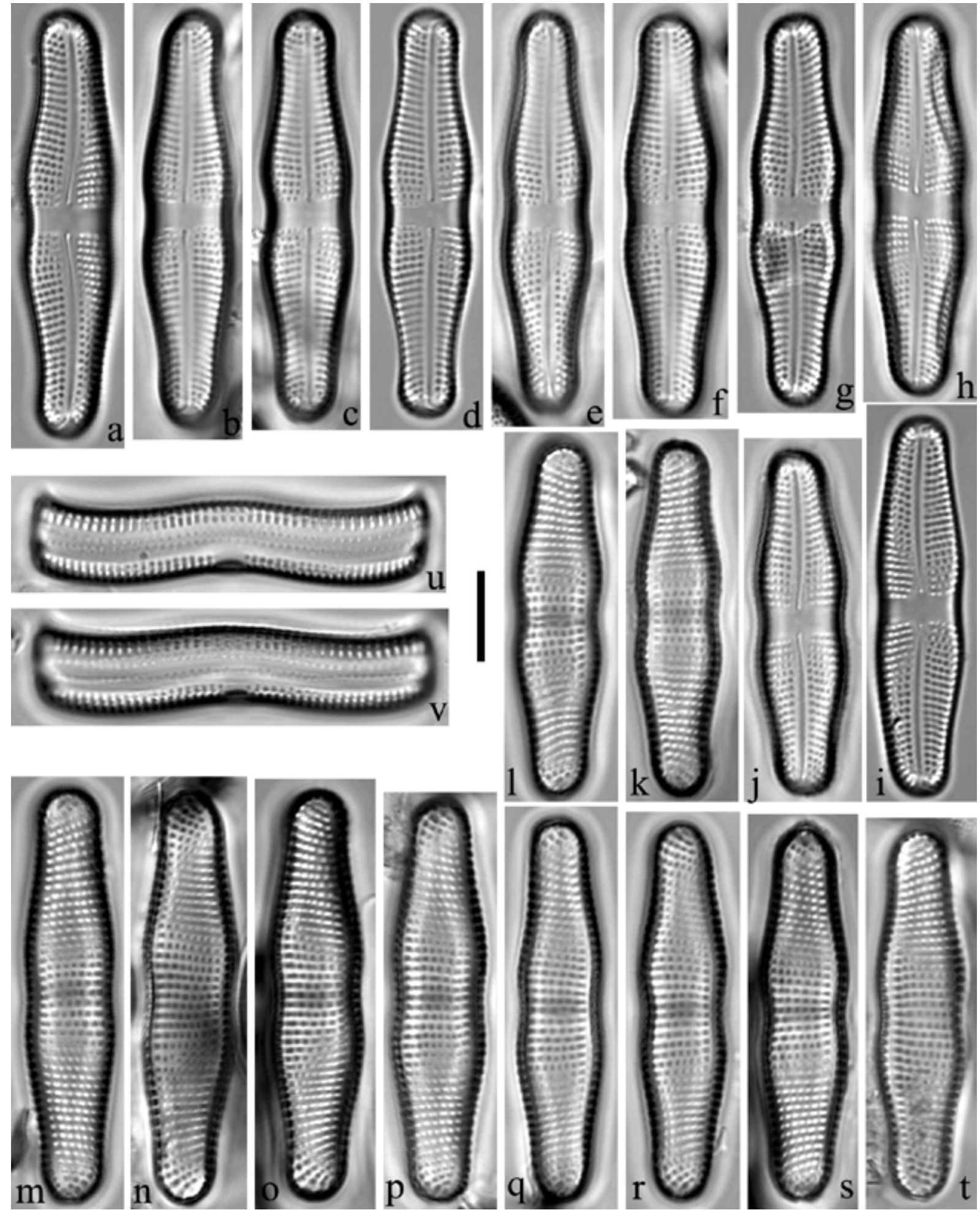

Figs 10a-v. Achnanthes pseudocoarctata sp. nov. LM, Cave near Royat, France: (10a-j) size diminution series of the R-valve, (10k-t) size diminution series of the $\mathrm{P}-\mathrm{valve},(10 \mathrm{u}-\mathrm{v})$ frustule in girdle view. Scale bar $10 \mu \mathrm{m}$. 


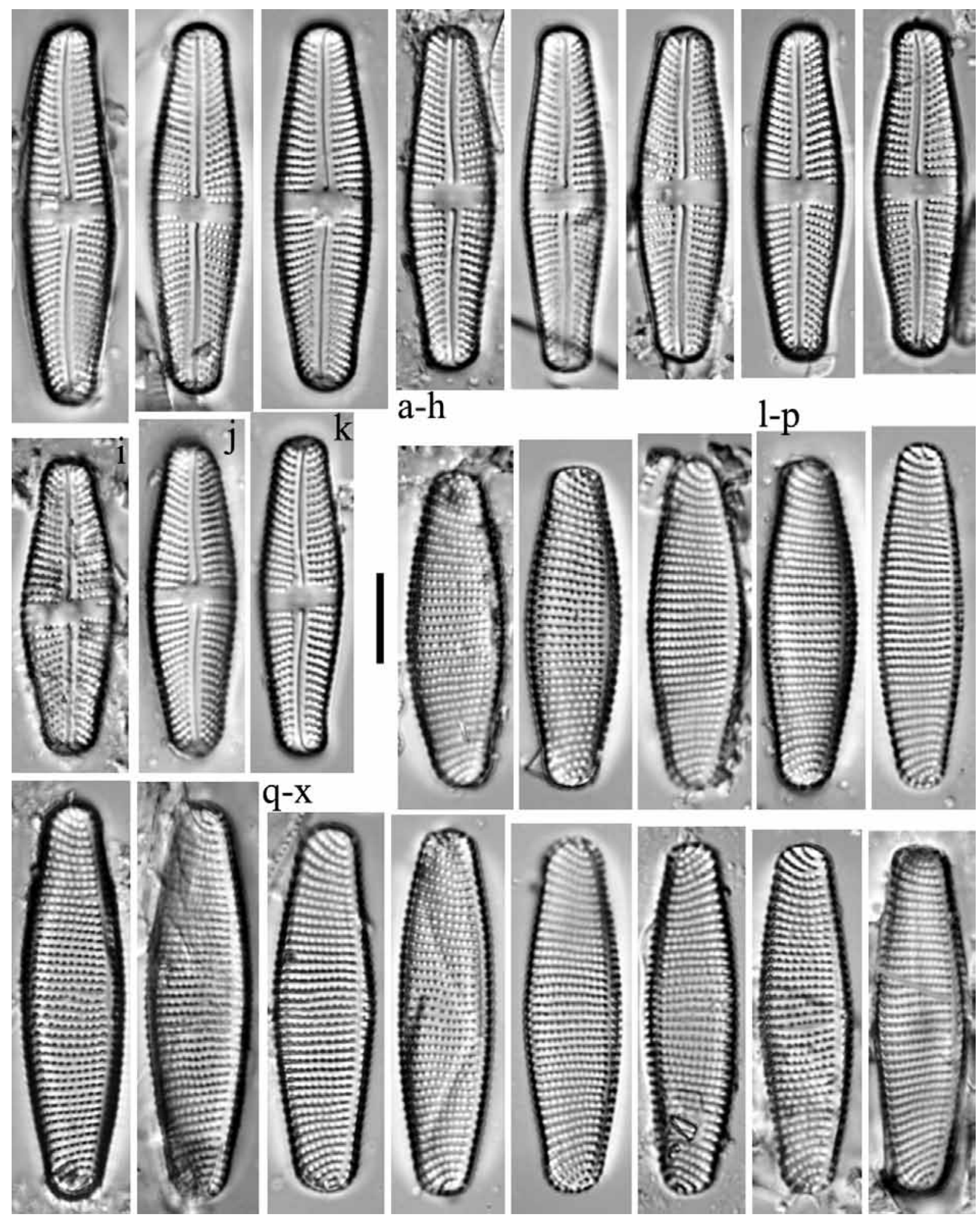

Figs 11a-x. Achnanthes sinaensis, LM, Osogovo Mountain, Macedonia: (11a-k) size diminution series of the R-valve, (111-x) size diminution series of the $\mathrm{P}-$ valve. Scale bar $10 \mu \mathrm{m}$. 

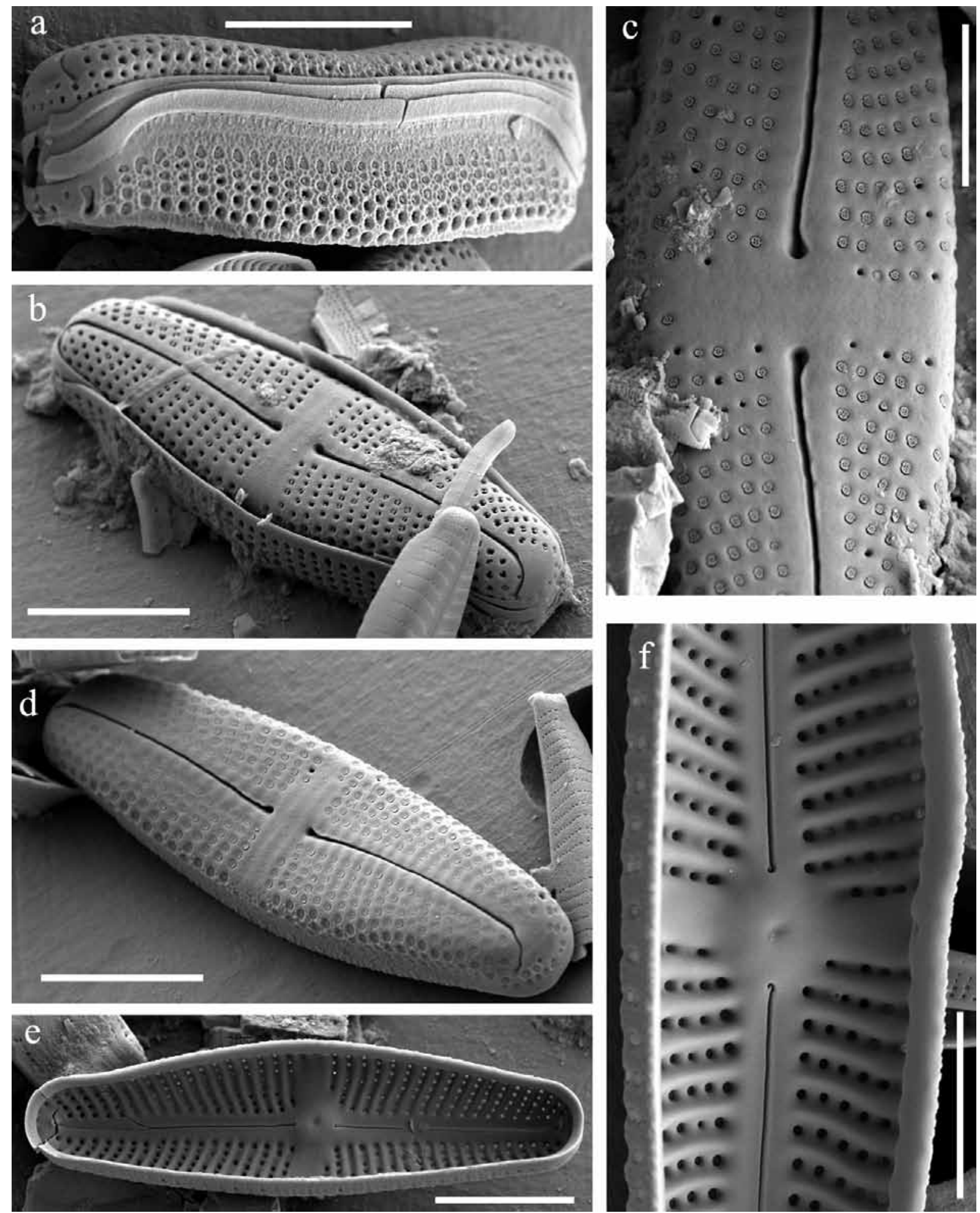

Figs 12a-f. Achnanthes sinaensis, SEM, LM, Osogovo Mountain, Macedonia: R-valve and frustule: (12a) frustule in girdle view, (12b, d) external valve view, (12c) detailed view of the mid-valve, (12e) internal valve view, (12f) detailed view of the mid-valve. Scale bar $10 \mu \mathrm{m}$ (Figs 12a, b, d, e), $5 \mu \mathrm{m}$ (Figs 12c, f). 

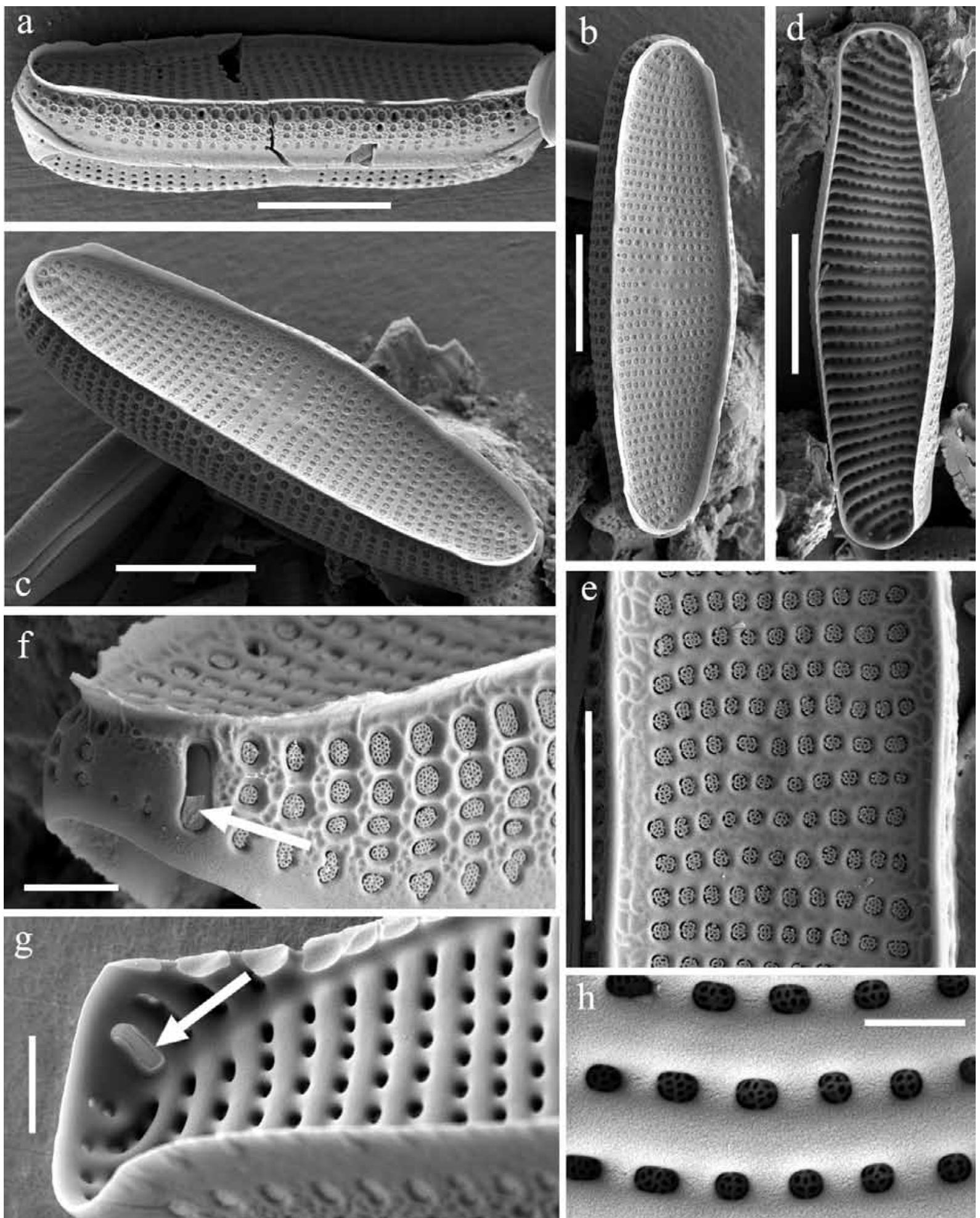

Figs 13a-h. Achnanthes sinaensis, SEM, LM, Osogovo Mountain, Macedonia: P-valve and frustule: (13a) frustule in girdle view, (13b, c) external valve view, (13d) internal valve view, (13e) detailed external view of the mid-valve, (13f) detail of the valve apex, (13g) detailed internal view of the valve apex, (13h) detailed internal view of virgae and areolae. Scale bar $10 \mu \mathrm{m}$ (Figs 13a-d), $5 \mu \mathrm{m}(13 \mathrm{e}), 2 \mu \mathrm{m}(13 \mathrm{f}, \mathrm{g})$, $1 \mu \mathrm{m}(13 \mathrm{~h})$. 

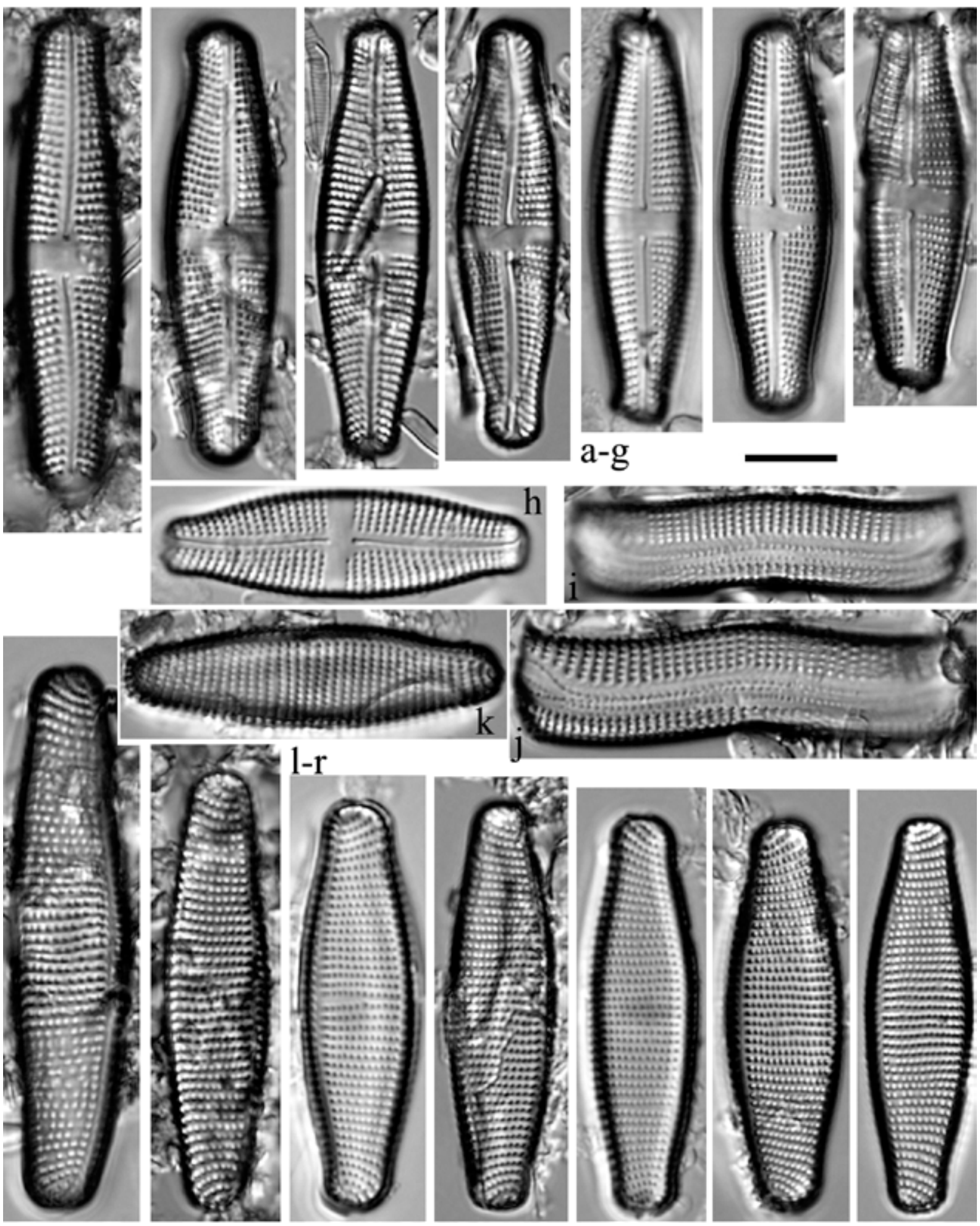

Figs 14a-r. Achnanthes sinanensis, LM, Dschebel Musa, Sinai Peninsula: (14a-h) size diminution series of the R-valve, (14i-j) frustule in girdle view, (14k-r) size diminution series of the P-valve. Scale bar $10 \mu \mathrm{m}$. 

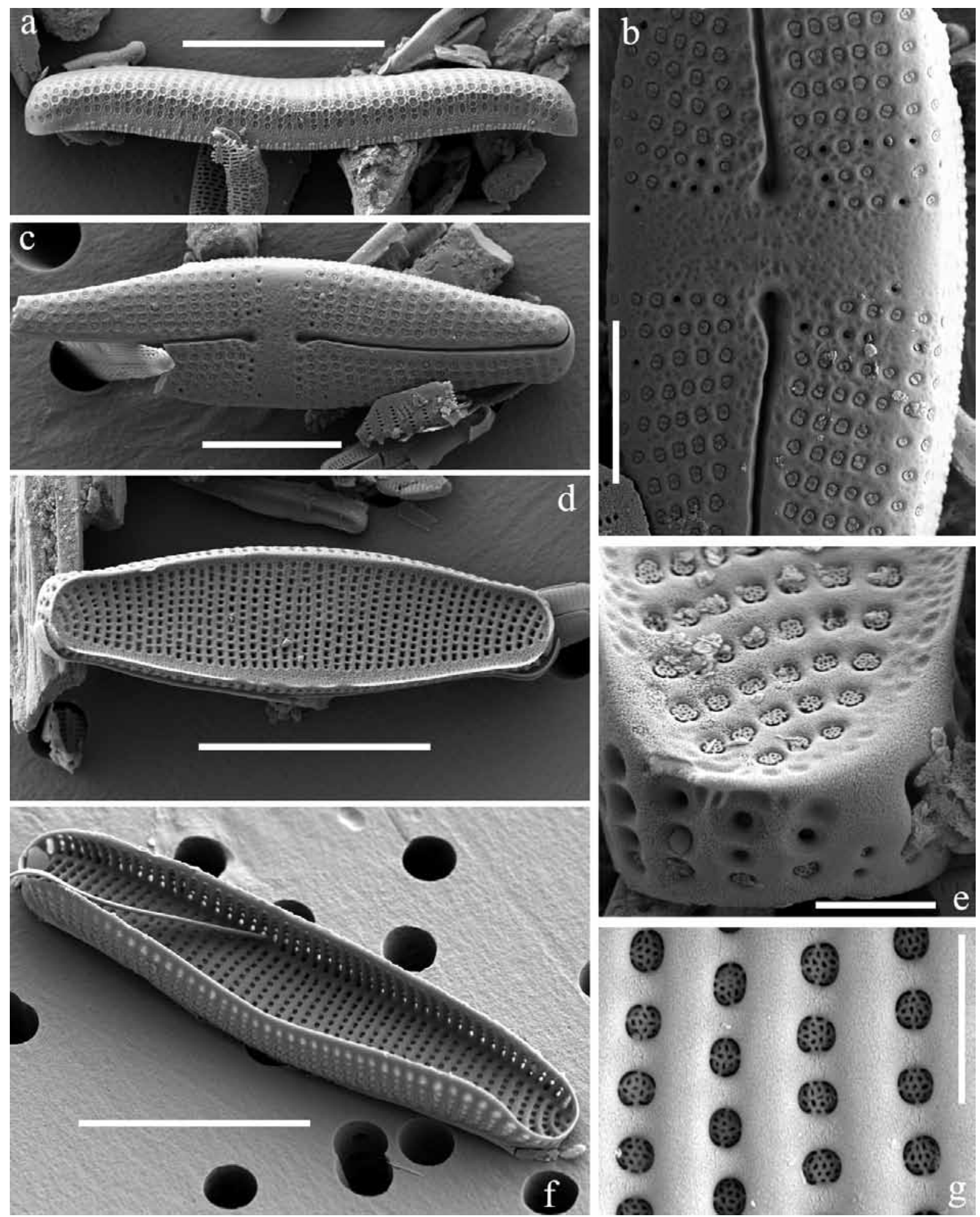

Figs 15a-g. Achnanthes sinaensis, SEM, Dschebel Musa, Sinai Peninsula: R-and P-valve: (15a) R-valve in girdle view, (15b) detailed view of the mid-valve of the R-valve, (15c) external view of the P-valve, (15d) external view of the $\mathrm{R}$-valve, (15e) detailed view of the valve apex, (15f) internal view of the P-valve, (15g) detailed internal view of virgae and areolae. Scale bar $20 \mu \mathrm{m}$ (Figs 15a, d, f), $10 \mu \mathrm{m}$ (Fig. 15c), $5 \mu \mathrm{m}$ (Fig. 15b), $2 \mu \mathrm{m}$ (Figs 15e, g). 


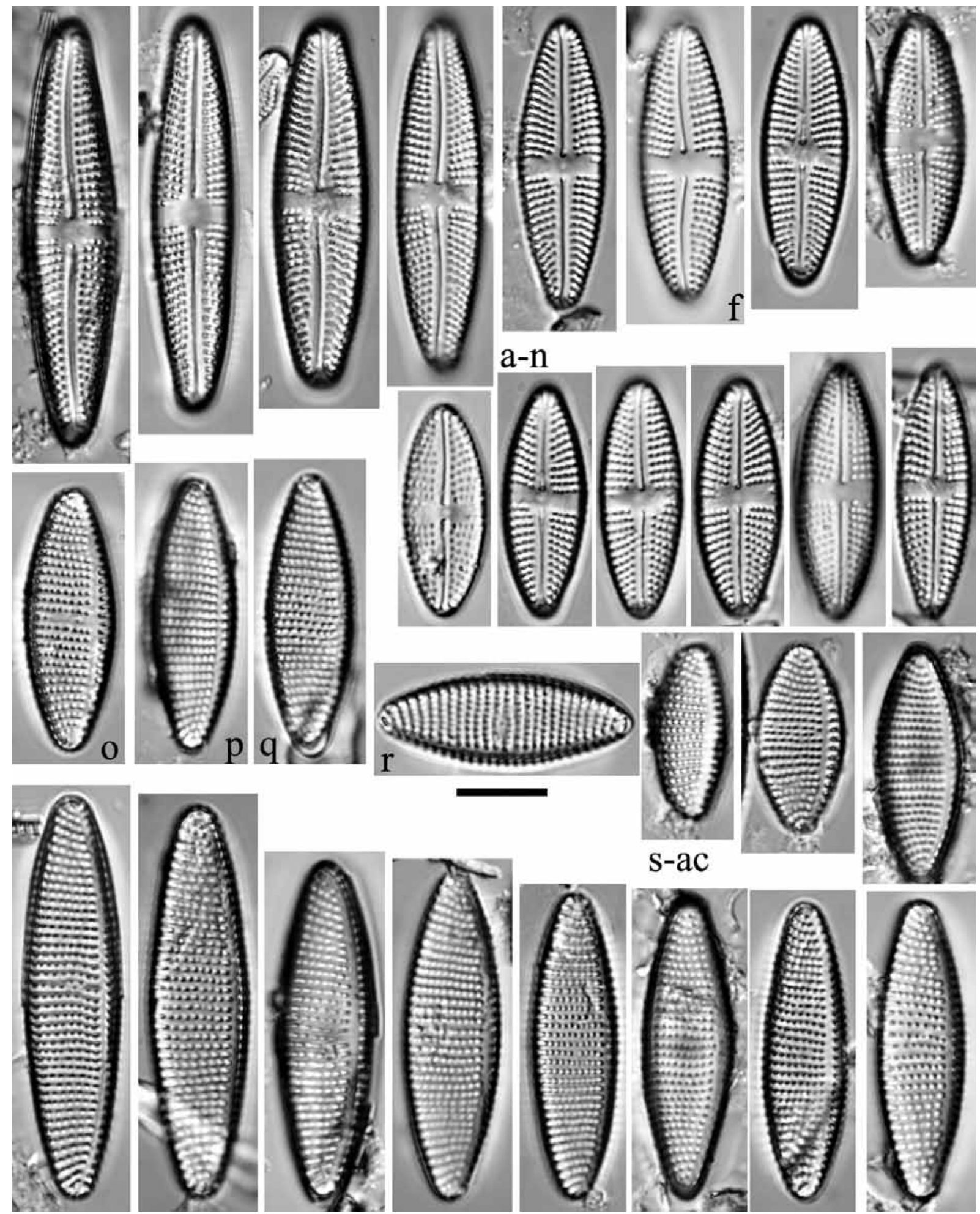

Figs 16a-ac. Achnanthes prominula sp. nov., LM, Cave Peshti, Macedonia: (16a-n) size diminution series of the R-valve, (16o-ac) size diminution series of the P-valve. Fig. 16f represents the holotype. Scale bar $10 \mu \mathrm{m}$. 

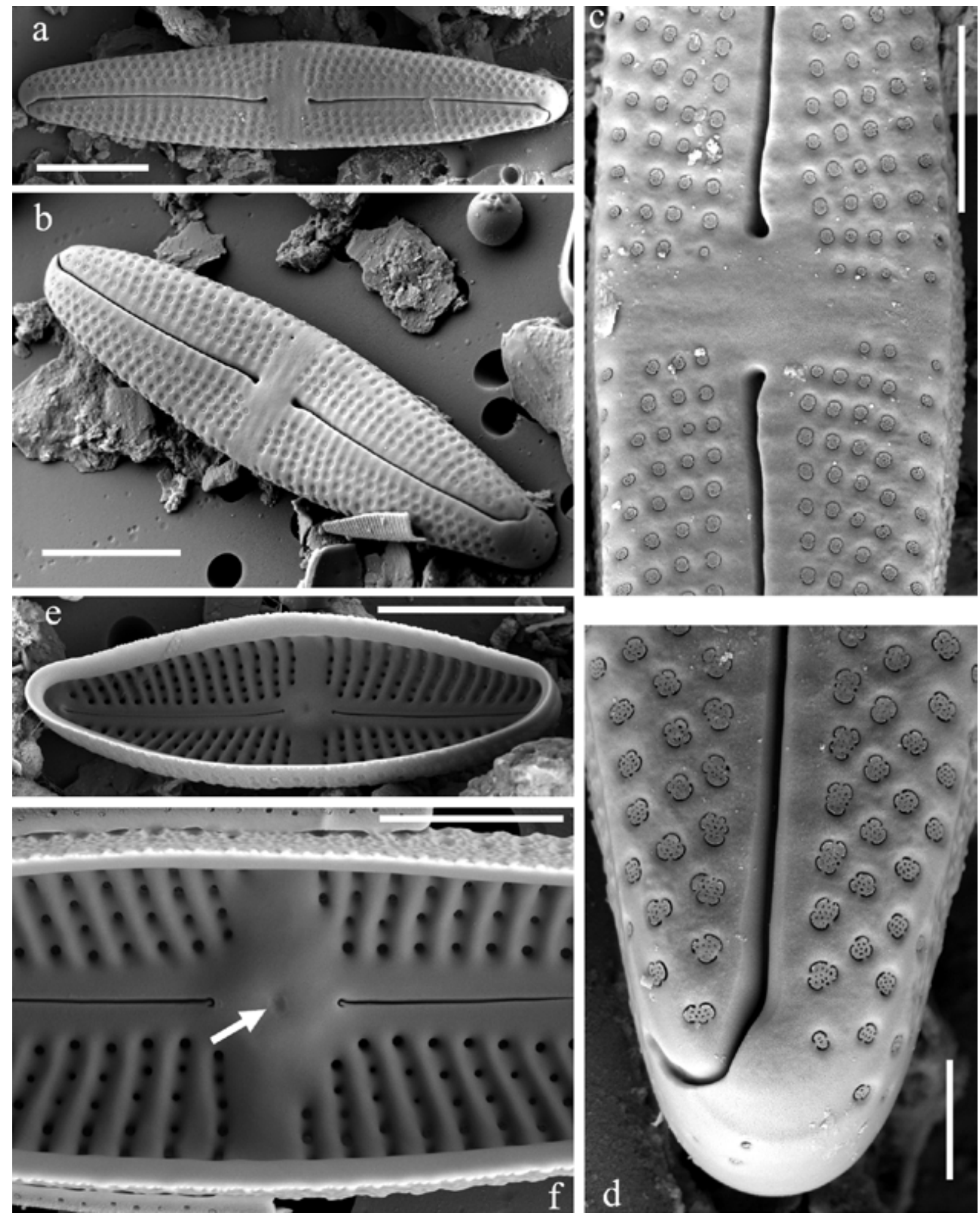

Figs 17a-f. Achnanthes prominula sp. nov., SEM, Cave Peshti, Macedonia: R-valve: (17a, b) external valve view, (17c) detailed view of the mid-valve, (17d) detailed view of the valve apex, (17e) internal valve view, (17f) detailed view of the mid-valve. Scale bar $10 \mu \mathrm{m}(17 \mathrm{a}, \mathrm{b}, \mathrm{e})$, $5 \mu \mathrm{m}(17 \mathrm{c}, \mathrm{f}), 2 \mu \mathrm{m}(17 \mathrm{~d})$. 

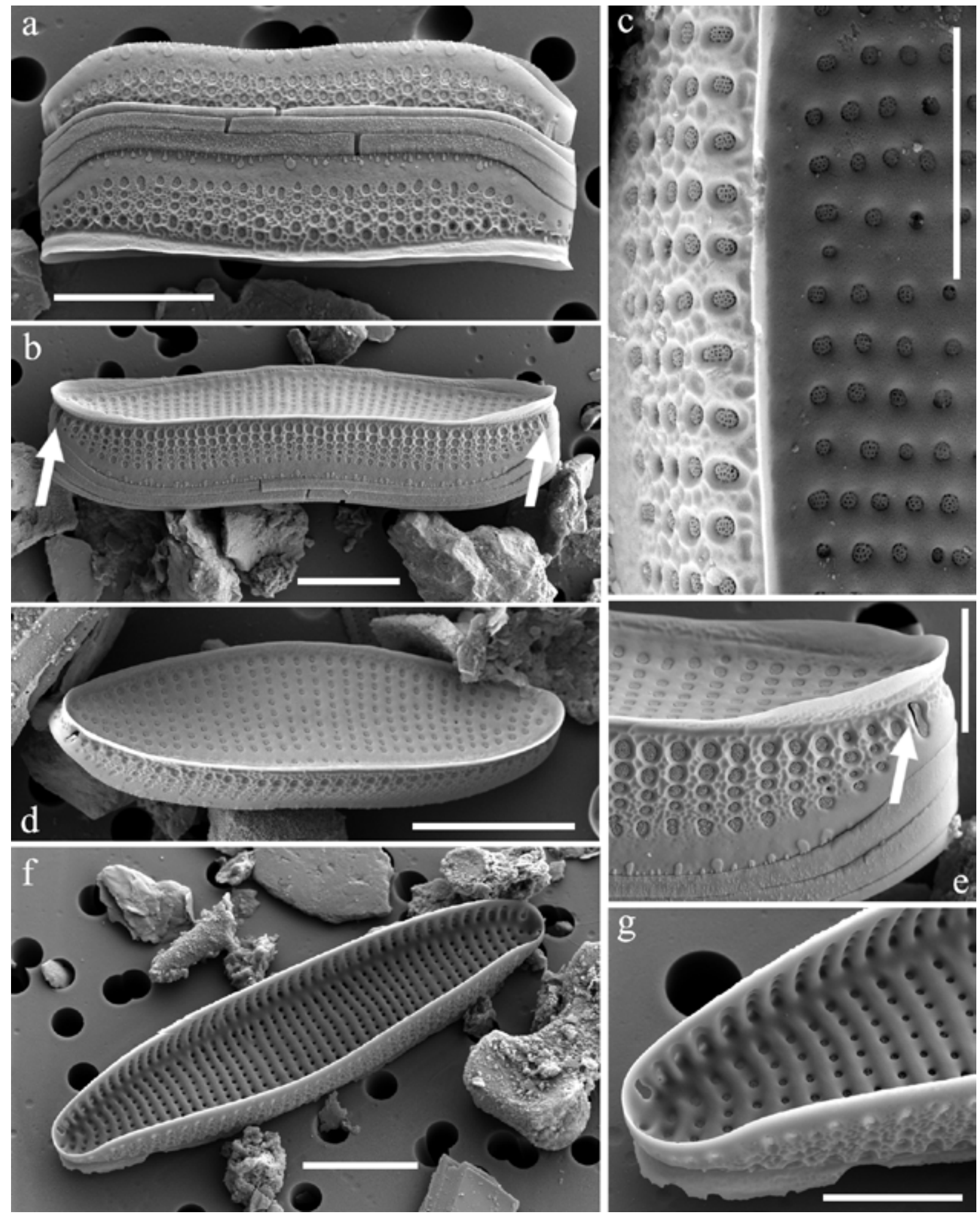

Figs 18a-g. Achnanthes prominula sp. nov., SEM, Cave Peshti, Macedonia: P-valve and frustule: (18a) frustule in girdle view, (18b, d) external valve view, (18c) detailed view of the mid-valve with marginal ridge and valve face and mantle, (18e) detailed view of the valve apex, (18f) internal valve view, (18g) detail of the valve apex. Scale bar $10 \mu \mathrm{m}$ (18a, b, d, f), $5 \mu \mathrm{m}(18 \mathrm{c}, \mathrm{e}, \mathrm{g})$. 

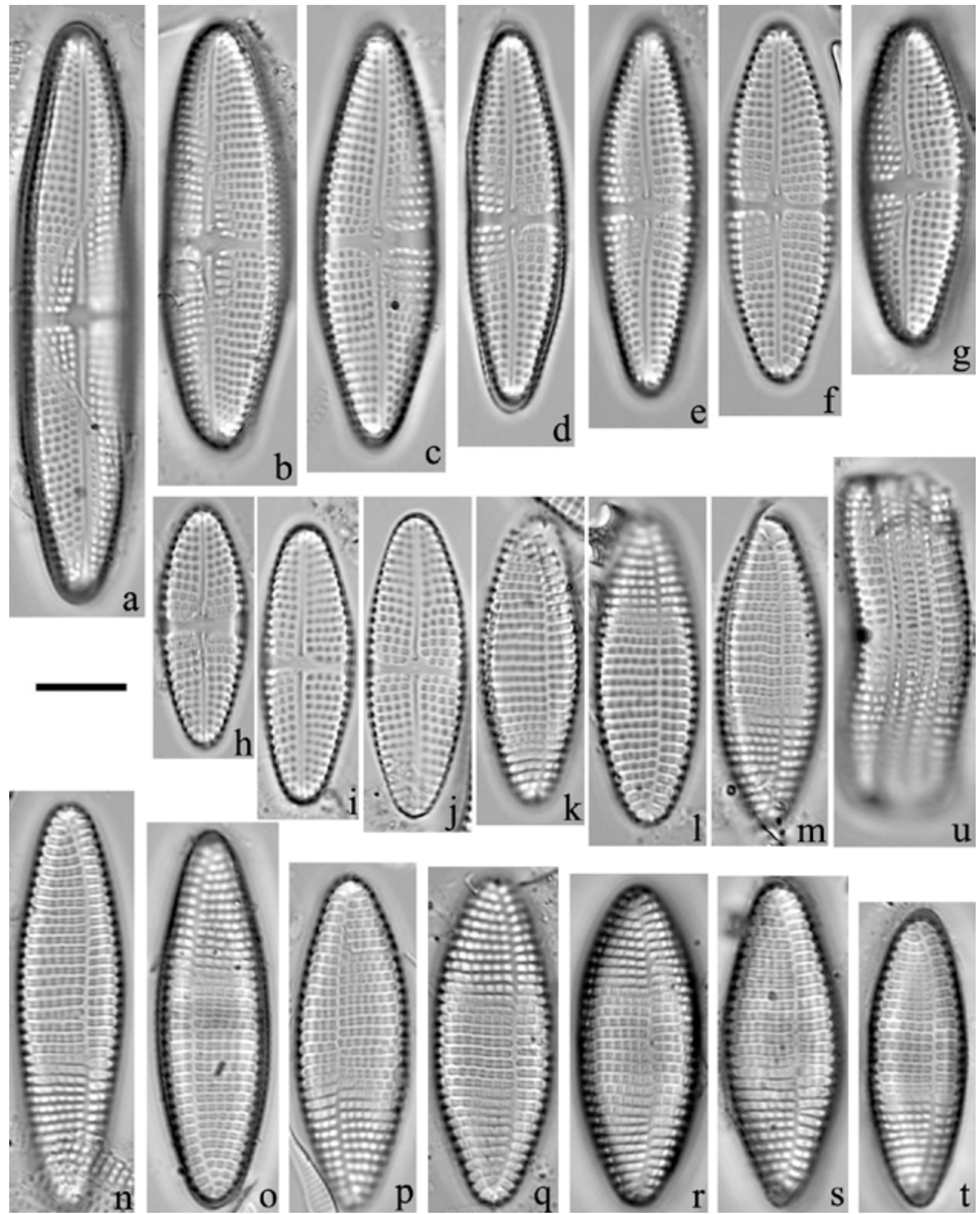

Figs 19a-u. Achnanthes intermedia, LM, near Berlin, Germany: (19a-j) size diminution series of the $\mathrm{R}-\mathrm{valve},(19 \mathrm{k}-\mathrm{t})$ size diminution series of the P-valve, (19u) frustule in girdle view. Scale bar $10 \mu \mathrm{m}$ 
on Kützing's type slides and materials I: New morphological information on Achnanthes brevipes var. intermedia (Kütz.) Cleve. - Diatom 20: 159-165.

Toyoda, K. \& Williams, D.M. (2005): A proposal to designate a lectotype for Achnanthes smithiana (Grev.) comb. nov. - Diatom 21: 131-133.

Toyoda, K.; Nagumo, T.; Osada, K. \& Tanaka, J. (2003): Morphological investigations of Achnanthes javanica Grunow and A. subconstricta (Meister) comb. nov. Diatom Research 18: 365-375.

Toyoda, K.; Cox, E.J.; Sims, P.A. \& Williams, D.M. (2005a): The typification of Achnanthes Bory based on Echinella stipitata Lyngbye, with an account of the morphology and fine structure of Lyngbye's species. - Diatom Research 20: 375-386.

Toyoda, K.; IdeI, M.; NAgumo, T. \& TANaKa, J. (2005b): Fine-structure of the vegetative frustule, perizonium and initial valve of Achnanthes yaquinensis (Bacillariophyta). - European Journal of Phycology 40: 269-279.

Toyoda, K.; Nagumo, T.; Tanaka, J. \& Williams, D.M. $(2005 \mathrm{c})$ : Taxonomy and fine structure of a marine diatom Achnanthes grunowii, nom. nov. - Journal of Japanese Botany 80: 1-8.

Toyoda, K.; Tanaka, J. \& Williams, D.M. (2006a):
Morphological note on the marine diatom Achnanthes longipes C.Agardh from Japanese material. - Diatom 22: 27-33.

Toyoda, K.; Williams, D.M.; Tanaka, J. \& Nagumo, T. (2006b): Morphological investigations of the frustule, perizonium and initial valves of the freshwater diatom Achnanthes crenulata Grunow (Bacillariophyceae). Phycological Research 54: 173-182.

Toyoda, K.; Tanaka, J. \& Williams, D.M. (2009): A new brackish water diatom, Achnanthes secretitaeniata, from Japan. - Journal of Japanese Botany 84: 19-26.

Toyoda, K.; Nagumo, T. \& Williams, D.M. (2010): A new marine monoraphid species, Achnanthes pseudolongipes sp. nov., from Miyagi, Japan. Diatom Research 25: 185-193.

Van de Vijver, B.; Frenot, Y. \& Beyens, L. (2002). Freshwater diatoms from Ile de la Possession (Crozet Archipelago, Subantarctica). - Bibliotheca Diatomologica 46: 1-412.

VanLandingham, S.L. (1967): Catalogue of the fossil and recent genera and species of diatoms and their synonyms. Part I. Acanthoceros through Bacillaria. 493 pp., J. Cramer, Lehre.

(C) Czech Phycological Society (2014)

Received August 20, 2013

Accepted October 25, 2013 